Linköping Studies in Science and Technology

Dissertation No. 2186

\title{
Multi-omic time-series \\ analysis of T-cells as a model for identification of \\ biomarkers, treatments and upstream disease regulators
}

Olof Rundquist

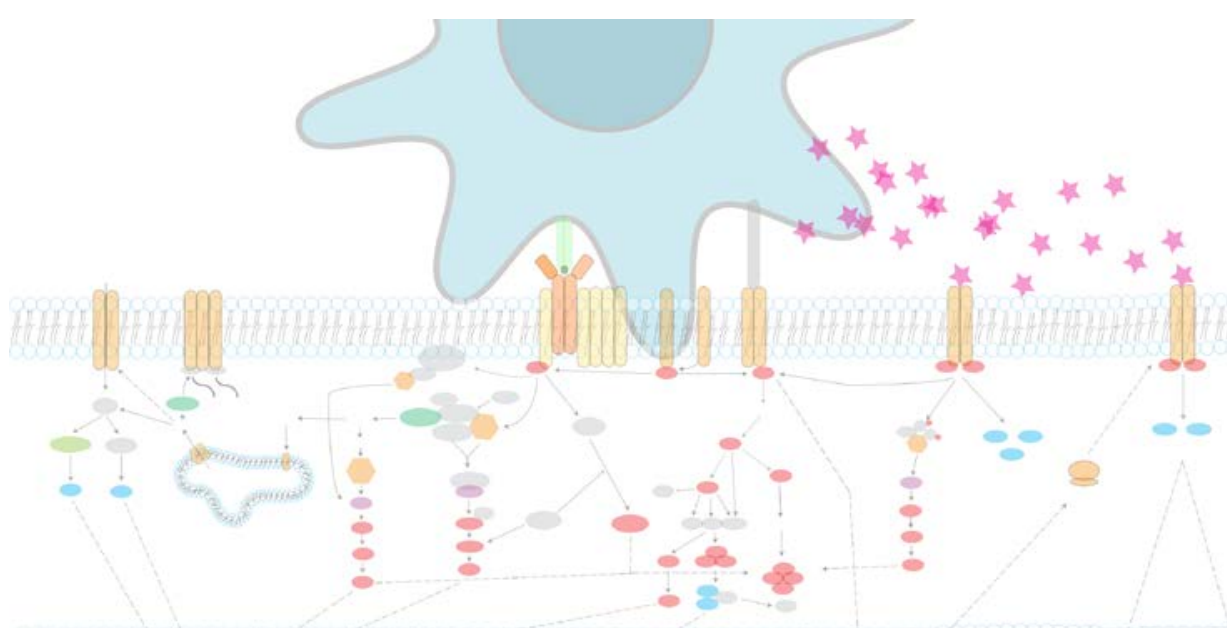



Linköping Studies in Science and Technology

Dissertation No. 2186

Multi-omic time-series analysis of T-cells as a model for identification of biomarkers, treatments and upstream disease regulators

\author{
Olof Rundquist
}

\title{
100 UNKKODNESS
}

Bioinformatics, IFM

Tekniska Fakulteten

Linköpings universitet, SE-581 83 Linköping, Sweden

Linköping 2021 
Copyright (C) Olof Rundquist, 2021

Printed in Sweden by LiU-Tryck, 2021

Published articles have been reprinted with permission from the respective copyright holder.

ISBN 978-91-7929-103-7 (print)

ISBN 978-91-7929-104-4 (PDF)

https://doi.org/9789179291044

ISSN 0345-7524 


\section{Supervisor}

Docent Mika Gustafsson

Bioinformatics, Department of Physics, Chemistry and Biology (IFM), Linköping University, Sweden.

\section{Co-supervisor}

Docent Colm E. Nestor

Crown Princess Victoria Children's Hospital (BKH), and Department of Biomedical and Clinical Sciences (BKV), Linköping University, Sweden.

\section{Faculty Opponent}

Professor Riitta Lahesmaa

Turku Bioscience Centre, University of Turku and Åbo Akademi University, Finland

\section{Examination Board}

Professor Jane Synnergren

Systems Biology Research Centre, School of Bioscience, University of Skövde, Skövde, Sweden.

Docent Jessica Nordlund

Department of Medical Sciences, Molecular Medicine and Science for Life Laboratory, Uppsala University, Sweden.

Docent Caludio Cantú

Department of Molecular medicine and Virology (MMV), and Department of Biomedical and Clinical Sciences (BKV), Linköping University, Sweden. 


\section{Abstract}

$\mathrm{CD} 4^{+} \mathrm{T}$-cell function and their process of differentiation is a central piece of the puzzle in a multitude of diseases. $\mathrm{CD} 4^{+} \mathrm{T}$-cells are part of the adaptive immune system and function by directing other immune cells to the site of infection and instructing B-cells to produce antibodies, among many other functions. $\mathrm{CD} 4^{+} \mathrm{T}$-cells may differentiate into several different sub-types, such as T-helper 1, 2 and 17, with differing functions within the immune system. Thelper 1 (Th1) cells are most closely associated with the elimination of viral infections but are also associated with autoimmune diseases such as multiple sclerosis (MS) and rheumatoid arthritis (RA). T-cells develop in the thymus first as double-negative T-cells, that express neither CD4 nor CD8, going through multiple development stages before becoming double-positive T-cell that express both $\mathrm{CD} 4$ and $\mathrm{CD} 8$, before eventually giving rise to single positive $\mathrm{CD}^{+}$and $\mathrm{CD} 8^{+} \mathrm{T}$-cells. This process of development is under tight control and if this control fails, cancer may result. Once $\mathrm{CD} 4^{+} \mathrm{T}$-cells are fully developed, they may specialize as outlined above and if said process is not properly controlled, autoimmunity may result. As such, the proper understanding of these control mechanisms is of great importance for the understanding of diseases of the immune system and the discovery of biomarkers and treatments against said diseases. These control processes are often studied in a singular fashion using one omic technique, e.g., RNA sequencing (RNA-seq), with the assumption that a signal in one omic layer will be reflected in another. Recent studies attempting to integrate multiple omics have however cast doubt on this and it is becoming increasingly apparent that to gain a complete understanding of a system, the system needs to be studied at multiple levels of regulation, i.e., multiple omics.

The aim of this thesis was to use multi-omics to investigate the development and differentiation process of $\mathrm{CD} 4^{+} \mathrm{T}$-helper cells and relate it to disease mechanisms. To start, we studied T-cell development through the model of Tcell acute lymphoblastic leukaemia (T-ALL). More specifically, we studied the TET2 gene and investigated its importance in T-ALL for treatment susceptibility and mechanism in vitro. TET2 is a demethylase and functions through the removal of cytosine methylation on the DNA, a marker of gene silencing. Through treatment with decitabine, an inhibitor of DNAmethylation, and Vitamin $\mathrm{C}$, a co-factor for TET2, we showed that TET2 deficient cancer cell lines were more vulnerable to treatment targeting DNA methylation and investigated the mechanistic effects of said treatment by RNA sequencing. We then moved on to study primary human naïve $\mathrm{CD} 4^{+} \mathrm{T}$-cells and their differentiation into Th1-cells. First, we focused on T-cell activation and its importance to MS to understand the role of T-cells in mediating the 
lowered disease activity usually observed during pregnancy in MS. This showed that the major pregnancy hormone progesterone significantly dampens T-cell activation, providing a possible explanation for the beneficial effects of pregnancy on MS. Then, using ATAC sequencing (ATAC-seq), RNA-seq and proteomics we studied Th1-differentiation as a time series to elucidate regulatory events throughout the differentiation process and to study their implications for MS with the inclusion of progesterone treatment. The integration of several omic techniques presents unique challenges as one does not necessarily directly translate to the other. As such, we first focused on the integration of RNA-seq and proteomics by designing a model for the prediction of protein abundance from RNA-seq and validated it through biomarker discovery. Next, we focused on the integration of ATAC-seq and RNA-seq using correlation between time series of the two techniques.

This thesis provides a thorough investigation of Th1-cell differentiation and its potential involvement in disease. Time series datasets were produced to study gene regulation (ATAC-seq), gene expression (RNA-seq) and protein expression (mass spectrometry) and the work focused on their integration. This profoundly showed that through combining multiple omic techniques it was possible to gain new insights that were not possible to discover with one or the other. Multi-omic analyses are becoming more and more common in medicine today as their power to produce new insight into the complexity of complex diseases is being increasingly recognized. As such, this work forms an important foundation for future discovery of biomarkers and treatments in such diseases. 


\section{Populärvetenskaplig sammanfattning}

T-hjälparceller och deras funktion inom immunförsvaret spelar en viktig del i orsaken och symptomen av många moderna sjukdomar. T-hjälparceller är en del av det specifika immunförsvaret och riktar in sig på att identifiera hot och leda immunsvaret mot dessa hot. Dock är T-hjälparceller inte felfria och kan i vissa fall angripa kroppens egna celler, så kallad autoimmunitet, eller ofarliga ämnen så som pollen, t.ex. vid allergi, vilket kan leda till sjukdom. Thjälparceller är också involverade i cancer, t.ex. T-cell akut lymfatisk leukemi (T-ALL) där underutvecklade T-hjälparceller förökar sig i stora mängder och på så vis slår ut övriga blodcellspopulationer. ALL är den vanligaste typen av leukemi hos barn och utgör $85-90 \%$ av alla fall, varav $15 \%$ är av T-cellstypen som har en markant sämre prognos. T-hjälparceller utvecklas från lymfocyter i brässen, även kallat tymus, och genomgår där en intensiv selektionsprocess där icke funktionella lymfocyter och lymfocyter som reagerar på kroppens egna celler, så kallade autoreaktiva celler, selekteras ut. Denna selektionsprocess är under strikt kontroll och det är när dessa processer fallerar som cancer och autoimmunitet kan uppstå. Dock är det inte nödvändigtvis tillräckligt att en icke fullt utvecklad cell undgår denna selektions process för att sjukdom ska utvecklas och viss autoreaktivitet tillåts även i T-hjälparceller så länge den inte är stark nog att orsaka skada. Oftast krävs att något ytterligare går fel för att sjukdom ska uppstå. I fallet vid cancer tar detta sin form i aktiveringen av gener som ökar tillväxt samt avstängning av gener som förhindrar den. Detta kan ske antigen igenom mutationer av genen, för att modifiera eller slå ut dess funktion, eller igenom genreglering, för att producera mer eller mindre av proteinet som genen kodar för. Vid autoimmunitet har felreglering av Thjälparceller förmåga att specialisera sig och rikta in sig på bekämpningen av olika typer av infektioner, så kallat differentiering, pekats ut som en möjlig orsak. Ett exempel på en sådan sjukdom är multipel skleros (MS), en neurologisk sjukdom, där typ 1 T-hjälparceller (Th1), normalt förknippade med bekämpningen av virus, har pekats ut som centrala. Det är därför mycket viktigt att förstå hur de processer som styr utveckling och differentiering fungerar för att kunna utveckla effektiv behandling och biomarkörer för dessa sjukdomar. För att studera hur dessa biologiska system fungerar krävs metoder som ger en omfattande bild av hur gener uttrycks och regleras kopplat till protein uttryck, så kallade omik metoder. Traditionellt har dessa processer studerats från en vinkel i taget, oftast igenom RNA-sekvensering för att studera geners utryck, med antagandet att ett resultat $i$ ett led av reglering kommer att spegla sig i de andra. Ny forskning med det parallella användandet av flera omik metoder har dock lett till att detta har börjat ifrågasättas och det börjar bli mer och mer erkänt att för att förstå ett biologiskt system så som Thjälparceller krävs att det studeras på flera nivåer av reglering samtidigt. 
Syftet med denna avhandling var att genom analyserande av flera omik studera T-hjälparcellers utveckling och differentiering för att ge en utökad förståelse av detta biologiska system och insikt i sjukdomsmekanismer. I första arbetet studerade vi T-hjälparcell utveckling med T-ALL som modell. Specifikt studerade vi genen TET2 som är inbladad i regleringen av genuttryck i Thjälparceller. TET2 reglerar genuttryck igenom att ta bort metylering av DNA, ett sätt att stänga av gener. TET2 har inte tidigare visats som en vital del i utvecklingen av T-ALL men genom studier av genuttryck kunde vi visa att TET2 är nedreglerad eller avstängd i $88 \%$ av T-ALL fallen. Vidare kunde vi även visa att cancer T-celler som inte utrycker TET2 var känsliga mot decitabin, även känt som Dacogen, ett läkemedel som hämmar DNAmetylering, samt att denna effekt förstärktes om vitamin C tillsattes, vitamin C krävs för att TET2 ska kunna utföra sin funktion. I det andra arbetet studerade vi sedan aktiveringen av T-hjälparceller och dess koppling till de mildare symptom som har observerats under graviteten hos MS patienter. Detta visade att graviditetshormonet progesteron markant hämmade aktiveringen av Thjälparceller vilket ger en möjlig förklaring till effekten som setts under graviditeten. Arbete tre och fyra fokuserade på att studera typ 1 T-hjälparcell differentiering genom att konstruera differentieringstidsserier och producera och interagera omik data för genreglering (ATAC-seq), genuttryck (RNA-seq) och proteinproduktion (masspektrometetri). Arbete tre fokuserade på integrationen av genuttryck och proteinproduktion och en matematisk modell utvecklades för att förutsäga mängden producerat protein baserat på genuttryck. Denna modell tillämpades sedan för att ta fram och verifiera en biomarkör i MS. Arbete fyra fokuserade på integrationen av data för genreglering och genuttryck via korrelationen av de två tidserierna, progesteronbehandling av cellerna inkluderades även för att studera dess effekt på typ $1 \mathrm{~T}$-hjälparcell differentiering.

Denna avhandling presenterar en grundlig studie av typ $1 \mathrm{~T}$-hjälparcellers differentiering och dess potentiella inblandning i sjukdom. Tidsseriedata producerades för att studera genreglering (ATAC-seq), genuttryck (RNA-seq) och proteinproduktion (masspektrometri) och arbetet fokuserade på deras integration. Detta visade att genom att för samma experimentuppställning samtidigt analysera flera omik-metoder var det möjligt att dra slutsatser som inte var möjliga med den ena eller den andra. Studier som använder flera omik metoder blir allt vanligare idag inom medicinsk forskning allt eftersom deras förmåga att producera ny kunskap om komplexa sjukdomar erkänns mer och mer. Denna avhandling formar därför en viktig grund för framtida upptäcker av biomarkörer och behandlingar inom dessa sjukdomar. 



\section{$\underline{\text { List of papers }}$}

I. TET2 as a tumor suppressor and therapeutic target in T-cell acute lymphoblastic leukemia

Maike Bensberg*, Olof Rundquist*, Aida Selimovic, Cathrine Lagerwall, Mikael Benson, Mika Gustafsson, Hartmut Vogt, Antonio Lentini, and Colm E. Nestor

PNAS, 2021, Vol 118, issue 36

*Authors contributed equally

II. Progesterone Dampens Immune Responses in In Vitro Activated CD4 ${ }^{+} \mathrm{T}$ Cells and Affects Genes Associated With Autoimmune Diseases That Improve During Pregnancy

Sandra Hellberg, Johanna Raffetseder, Olof Rundquist, Rasmus Magnusson, Georgia Papapavlou, Maria C. Jenmalm, Jan Ernerudh and Mika Gustafsson

Frontiers Immunology, 2021, 12:672168

III. RNA-sequencing and mass-spectrometry proteomic time-series analysis of $\mathbf{T}$-cell differentiation identified multiple splice variants models that predicted validated protein biomarkers in inflammatory diseases

Rasmus Magnusson*, Olof Rundquist*, Min Jung Kim, Sandra Hellberg, Chan Hyun Na, Mikael Benson, David Gomez-Cabrero, Ingrid Kockum, Jesper Tegnér, Fredrik Piehl, Maja Jagodic, Johan Mellergård, Claudio Altafini, Jan Ernerudh, Maria C. Jenmalm, Colm E. Nestor, Min-Sik Kim and Mika Gustafsson

Manuscript, submitted

*Authors contributed equally

IV. Progesterone inhibits the establishment of the TH1-associated chromatin state in naïve $\mathbf{T}$-cells

Olof Rundquist, Colm E. Nestor, Jan Ernerudh, Maria Jenmalm, Sandra Hellberg and Mika Gustafsson

Manuscript 


\section{List of Associated papers not included in thesis}

- 5-Hydroxymethylcytosine Remodeling Precedes Lineage Specification during Differentiation of Human CD4(+) T Cells

Colm E Nestor, Antonio Lentini, Cathrine Hägg Nilsson, Danuta R Gawel, Mika Gustafsson, Lina Mattson, Hui Wang, Olof Rundquist, Richard R Meehan, Bernward Klocke, Martin Seifert, Stefanie M Hauck, Helmut Laumen, Huan Zhang, Mikael Benson

Cell Reports, 2016 Jul 12;16(2):559-570.

- Using high-throughput multi-omics data to investigate structural balance in elementary gene regulatory network motifs

Alberto Zenere, Olof Rundquist, Mika Gustafsson, Claudio Altafini

Bioinformatics, 2021 Aug 12 


\section{Table of Contents}

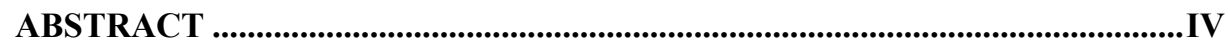

POPULÄRVETENSKAPLIG SAMMANFATTNING ............................................VI

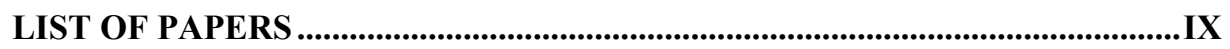

LIST OF ASSOCIATED PAPERS NOT INCLUDED IN THESIS.......................... X

TABLE OF CONTENTS ...........................................................................................XI

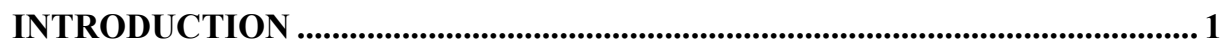

THE T-HELPER LINEAGE ......................................................................... 1

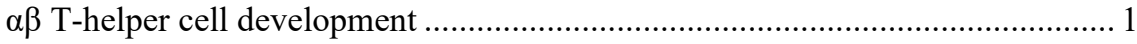

$\mathrm{CD}^{+} \alpha \beta$ T-cell function and differentiation into effector subtypes....................... 3

Type 1 T-helper cell differentiation ................................................................ 5

THE CD4 ${ }^{+}$T-HELPER CELL AS A DRIVER OF DISEASE ................................................. 8

T-cell Development in Malignant Transformation to T-ALL ................................ 8

DNA Methylation in Cancer .......................................................................... 9

The Breakdown of T-cell tolerance and autoimmunity........................................ 10

Endocrine influence on autoimmunity .............................................................. 11

Th1 in Multiple sclerosis and Rheumatoid arthritis ........................................... 12

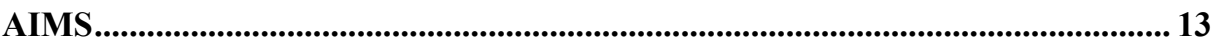

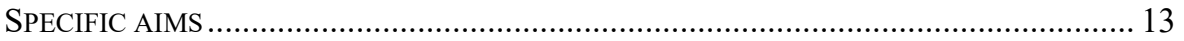

STUDY AND EXPERIMENTAL DESIGN ............................................................... 15

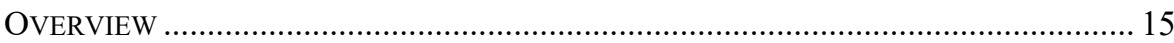

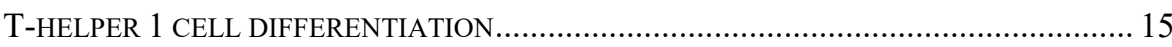

Time series design and methodological consideration for Th1 differentiation ... 15

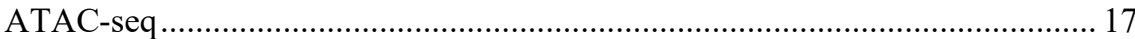

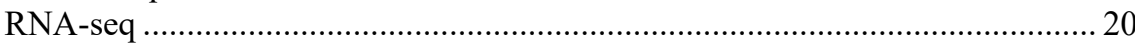

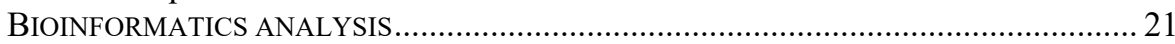

ATAC-seq pre-processing and methodological considerations ............................ 21

ATAC-seq peak calling and quantification ....................................................... 22

The calling of Transcription factor footprints and the matching of motifs ......... 24

RNA-seq pre-processing and methodological considerations.............................. 25

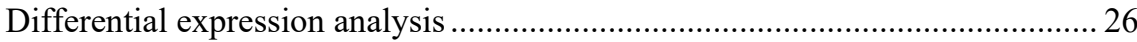

The integration of ATAC-seq and RNA-seq through correlation .......................... 27

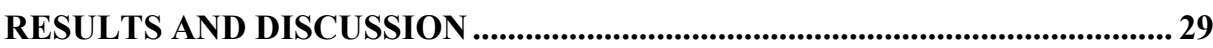

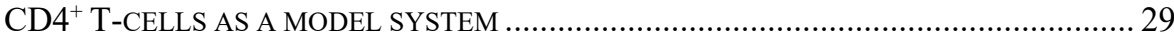

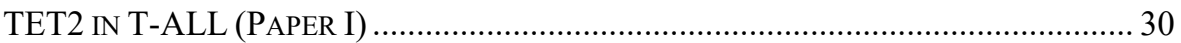


Pediatric T-ALL as a disease.

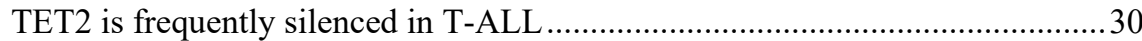

TET2 acts as a marker of sensitivity to the DNA demethylating agent decitabine

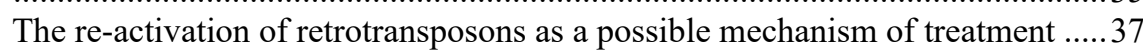

COMBINING OMIC TECHNIQUES IN T-CELLS (PAPER III AND IV) ..............................38

Constructing a model of mRNA to protein abundance (paper III) .......................38

Application of Model to RNA-seq allows for the discovery of Protein

Biomarkers

COMBINING ATAC-SEQ AND RNA-SEQ TO STUDY TH1 DIFFERENTIATION (PAPER IV)

MULTIPLE SCLEROSIS AS A DISEASE AND THE SIGNIFICANCE OF PREGNANCY (PAPER

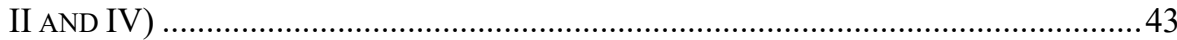

The effects of progesterone on T-cell activation ..............................................4 44

Progesterone downregulated genes and peaks are enriched for disease genes and

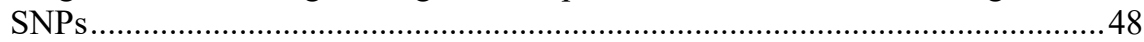

Analysis of RA and MS associated peaks implicates JUN as a central regulator of

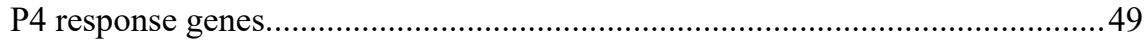

Long-term effects of P4 and influence on STATs..........................................51

CONCLUSIONS AND FUTURE PERSPECTIVES ............................................53

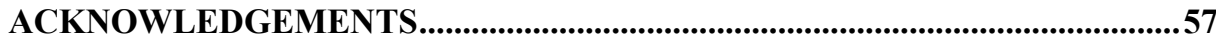

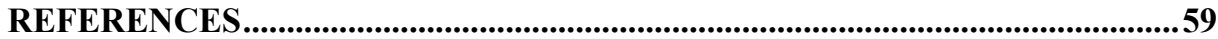




\section{Introduction}

\section{The T-helper lineage}

The immune system is divided into the innate and the adaptive immune system. The innate immune system is comprised of cells and proteins with pre-defined targets that act as the first line of defence against infection. The adaptive immune system on the other hand can adapt to external factors by maintaining sets of cells that may react to a variety of targets. The main focus of this thesis is on $\mathrm{CD} 4^{+} \alpha \beta \mathrm{T}$-helper cells, commonly known as T-helper cells, which are a critical component of the adaptive immune system.

\section{$\alpha \beta$ T-helper cell development}

T-helper cells develop from thymic T-cell progenitor cells (TSP) in the thymus. This development has been extensively studied and outlined in mice (Blom and Spits, 2006), however while the development is not as well-defined in humans it never the less passes through the same general steps. Development begins with TSPs originating in the bone marrow entering the cortex region of the thymus where they develop into early thymic progenitor cells (ETP). ETPs then commit to T-cell development, gaining expression of the cell surface marker CD1a (Blom and Spits, 2006), and become double negative cells (DN), known as such as they express neither of the T-cell lineage markers, CD4 and CD8. The DN cells then undergo several developmental stages driven by NOTCH and IL7 signalling, becoming DN3 cells after several rounds of clonal expansion. At the DN3 stage DNs start expressing the T-cell receptor (TCR). The TCR is similar to an antibody, it has a fixed and a variable domain and is made up of two out of four possible chains called $\alpha, \beta, \gamma$ and $\delta$. The DN3 then undergo TCR rearrangement in a stepwise fashion $(\delta>\gamma>\beta>\alpha)$ where the variable region of the TCR chain is scrambled to achieve antigen specificity. This scrambling of the variable region causes many DNs to express a non-functional TCR and 
they are summarily deleted through death by neglect. DNs which at this stage express TCR $\delta \gamma$ go onto become $\delta \gamma$ T-cells while DNs expressing TCR $\alpha \beta$ go onto become $\alpha \beta$ T-helper cells. DNs that survive this stage, 3-5\% (Egerton et al., 1990), start expressing both CD4 and CD8 becoming double positive cells (DP). The TCR localizing complex CD3 is then expressed leading to the expression of a fully functional TCR. Thereafter, DPs go through a selection process where cells producing low-avidity interactions with major histocompatibility complex (MHC) presented ligands are positively selected and promoted to further develop into either CD4 or CD8 expressing single positive cells (SP), while DPs that show high-avidity interactions are negatively selected and killed. This negative selection prevents the development of autoreactive T-cells and as such protects against autoimmunity. The DPs then pass into the medulla where they develop into SPs and go through a second round of negative selection before maturing into fully developed T-cells and passing into the blood circulation. (Jin et al., 2012; Klein et al., 2014; Takahama, 2006) (Figure 1). 


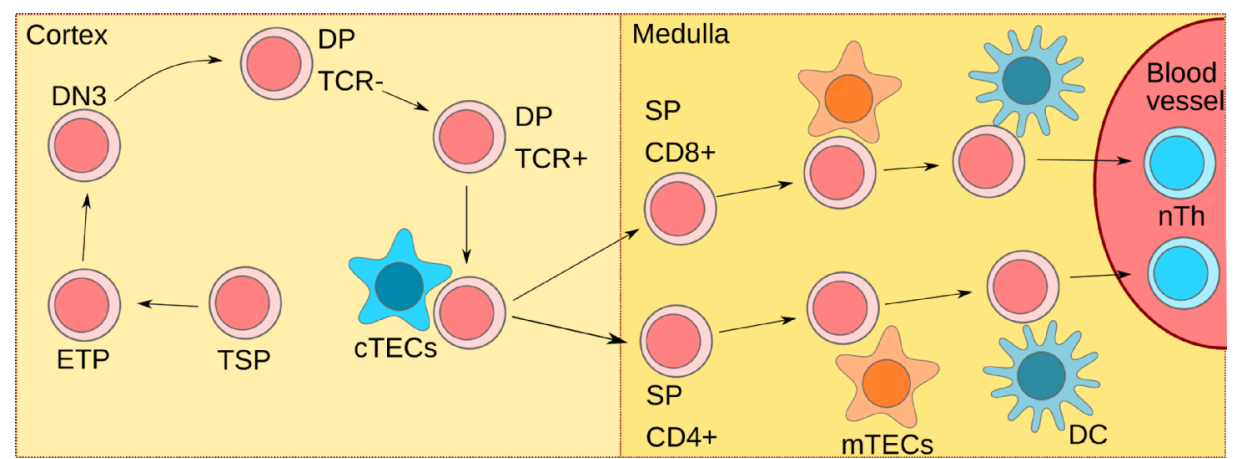

Figure 1: The T-cell development in the thymus. T-cell progenitor cells (TSP) originating in the bone-marrow enter the thymus and develop into early thymic progenitor cells (ETP), also known as double negative (DN) cells as they express neither CD4 nor CD8. The cells then go through the DN1 and 2 stages, before arriving at the DN3 stage where they undergo TCR rearrangement and start expressing both CD4 and CD8 becoming double positive cells (DP). The DPs then go through positive and negative selection through interacting with cortex thymic epithelial cells (cTECs). The DPs then pass through to the medulla where they develop into their CD8 or CD4 single positive (SP) counterparts. In the medulla the SPs then undergo a second round of negative selection through interactions with medullary thymic epithelial cells (mTECs) and resident as well as migratory immune cells such as dendritic cells (DC) before passing into the blood as fully mature naïve T-cells (nTh).

\section{$\mathrm{CD4}^{+} \alpha \beta$ T-cell function and differentiation into effector subtypes}

The main functionality of $\mathrm{CD}^{+} \mathrm{Th}$ cells is to recognize antigens presented on the surface of cells throughout the body and orchestrate an appropriate immune response towards the source of said antigen. $\mathrm{CD}^{+}$ T-helper cells emerge from the thymus as $\mathrm{CD}^{+}$naïve T-helper (nTh) cells and circulate throughout the body through the circulatory system looking for antigen presenting cells (APCs). Antigens are presented on the surface of APCs through a protein complex known as the major histocompatibility complex (MHC), also known as the human leukocyte antigen (HLA) in humans. When a nTh cell encounters an APC it binds to the MHC complex on the APC with the TCR initiating the activation of the T-cell. This interaction between the MHC complex and the TCR leads to the phosphorylation of the TCRs co-associating complex, CD3, 


\section{Olof Rundquist}

which in turn recruits the kinase ZAP70. ZAP70 then carries on the signal of activation through the phosphorylation of downstream factors, leading to the expression of chemokines and cytokines such as IL2. Tcell activation also leads to gain of surface marker expression such as CD69 and CD25 as well as the loss of expression of the nTh marker CD45RA. For full activation of a T-cell, TCR activation alone however is not sufficient, co-stimulation of co-stimulatory factors such as CD28 is also required through binding of CD28 to its respective ligands CD80 and CD86 on the APC (Smith-Garvin et al., 2009)(Figure 2).

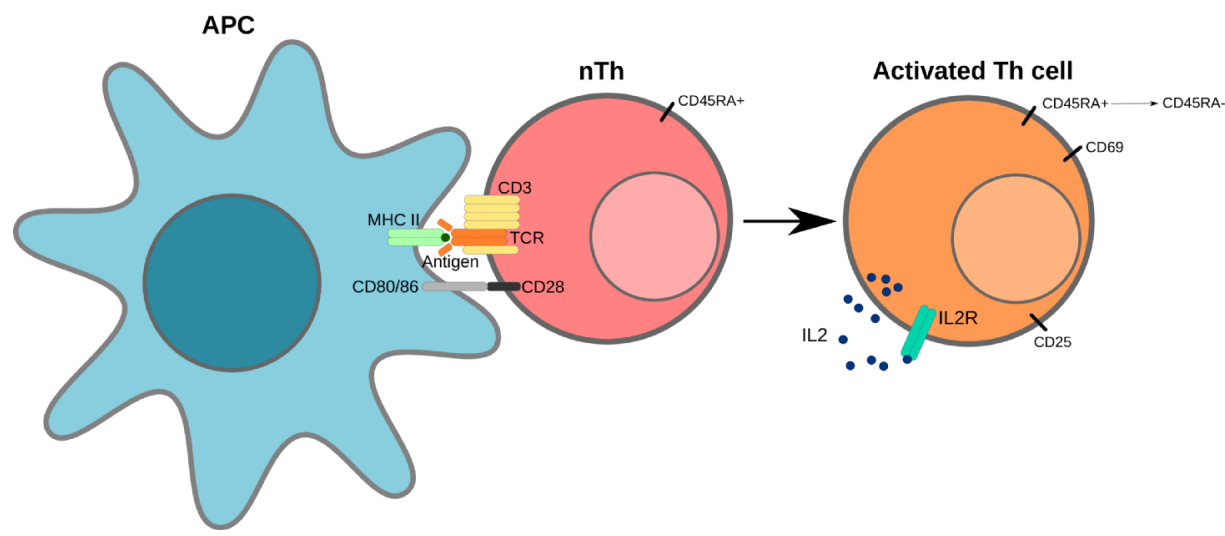

Figure 2: T-cell activation and subsequent cell surface marker expression. Antigens, presented by MHCII on APCs, bind to the TCR. Upon co-stimulation through interaction of CD80/86 and CD28, $\mathrm{CD} 4{ }^{+} \mathrm{T}$-cells become activated. This leads to the expression of several surface markers typical of activated T-cells such as CD69 and CD25 as well as cytokine expression. Additionally the naïve T-cell marker CD45RA is lost upon activation.

TCR binding in the absence of co-stimulation instead leads to anergy where the T-cell becomes unresponsive, promoting tolerance to the presented antigen (Schwartz, 2003). Following activation, depending on the local cytokine environment, the presence of co-stimulatory molecules and the type of APC, CD4 ${ }^{+} \mathrm{T}$-helper cells may further specialize into a variety of subtypes through a process known as differentiation. These subtypes include type 1, 2 and 17 T-helper cells (Th1, Th2 and Th17), regulatory T-cells (Treg) as well as other less 
well-defined subtypes such as type 9 and 22. These subtypes are defined by their expression of specific marker proteins and cytokines and are specialized towards specific functions such as fighting viral infections in the case of Th1 and immune regulation in the case of Treg but have also been associated with the development of allergy and autoimmune disorders (Luckheeram et al., 2012, p. 4) (Figure 3). Here we will focus on Th1 as an example of this biological system.

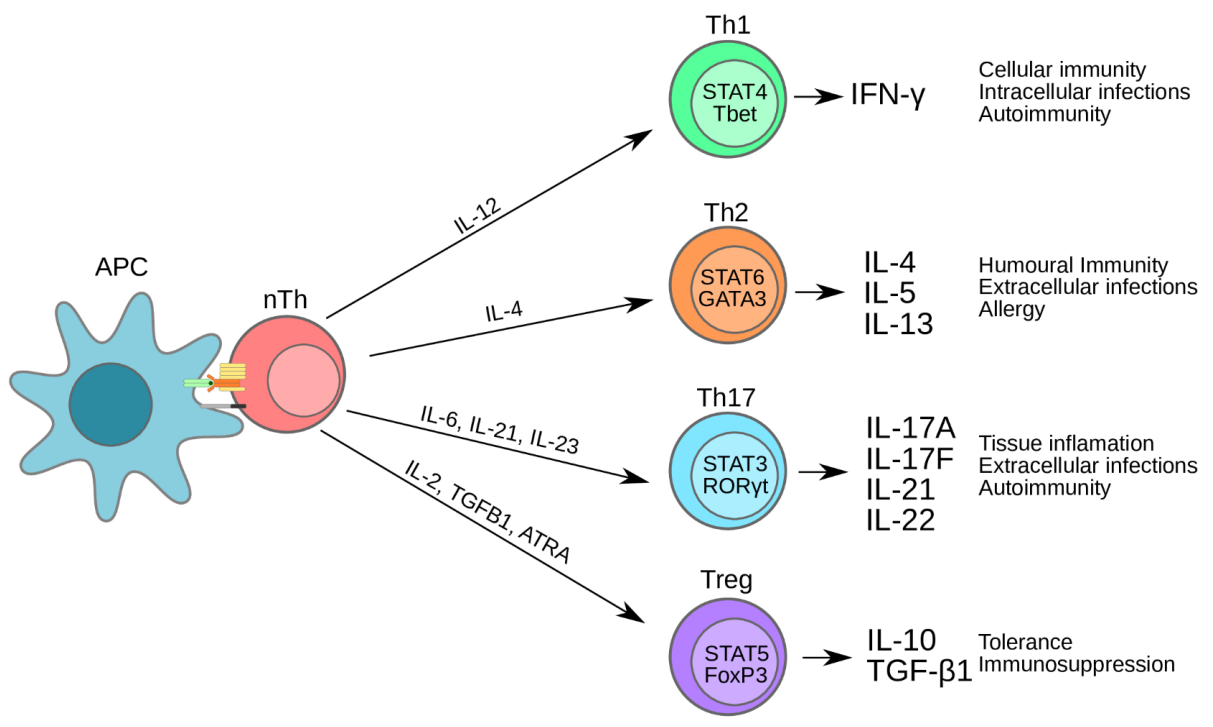

Figure 3: T-helper cell differentiation: Upon antigen presentation T-helper cells may differentiate into a number of different effector subtypes depending on the local availability of cytokines. These subtypes help direct immune responses against different types of infections but have also been associated with the development of allergy and autoimmune disorders.

\section{Type $1 \mathrm{~T}$-helper cell differentiation}

Th1 cells develop from nTh cells upon antigen binding and costimulation in the presence of the cytokine IL12, which is a short signalling protein produced by APCs activated in response to intracellular infections. During binding to the APC through the TCR, costimulation of CD28 leads to the expression of the IL12 receptor (IL12R $\beta 2$ ) which in turn binds IL12 resulting in the phosphorylation of STAT4. This, in combination with the TCR signal, leads to the 
activation of the master regulator of Th1 differentiation, T-bet (also known as TBX21), which is responsible for increasing the expression of IFNG and IL12Rß2. IFNG then activates STAT1, which further increases expression of T-bet creating a positive feedback loop where the continued expression of IFNG promotes the differentiation towards Th1 (Figure 4). Th1 cells have a wide variety of functions but are, as previously mentioned, most closely associated with intra-cellular infections where their production of IFNG attracts the innate immune system, specifically Natural killer cell (NK-cells), that in turn kill the infected cells through cell lysis (Luckheeram et al., 2012). 


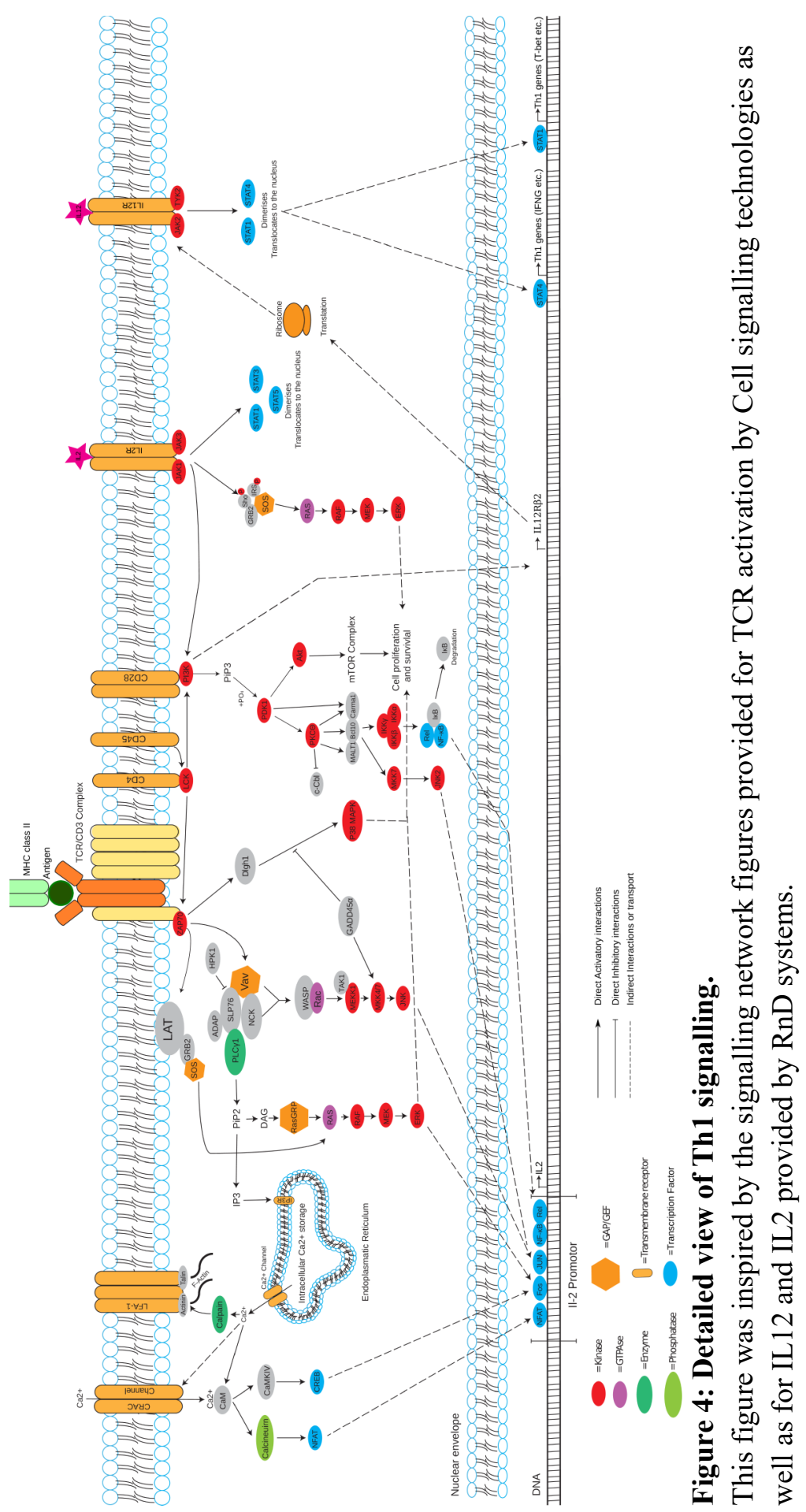




\section{The $\mathrm{CD} 4^{+} \mathrm{T}$-helper cell as a driver of disease}

$\mathrm{CD}^{+} \mathrm{T}$-helper cells beyond their vital functions within the immune system have also been implicated as major drivers of disease in both cancers and autoimmune disorders. Cancers developing from the T-cell arm of the immune system can develop from both premature T-cells in the thymus and bone marrow as well as the T-cells in the periphery, with the capacity to cause both leukaemia and lymphoma. $\mathrm{CD} 4^{+} \mathrm{T}$ helper cells are also vital to the development of cancer in an indirect sense as Tregs have been shown to significantly contribute to the immunosuppressive nature of the tumour micro environment allowing cancer cells to escape immune recognition and subsequent elimination (Li et al., 2020). CD4 ${ }^{+}$T-helper cells have also been directly implicated in autoimmunity as autoreactive Th cells have been isolated in patients suffering from Multiple sclerosis (MS) (Sospedra and Martin, 2005) and Rheumatoid Arthritis (RA) (Wehr et al., 2019). Here we will focus on (i) the development of T-ALL from progenitor T-cells and (ii) how Tcell differentiation relates to autoimmunity.

\section{T-cell Development in Malignant Transformation to T-} ALL

T-cell acute lymphoblastic leukaemia (T-ALL) is a subtype of ALL making up $15 \%$ of all paediatric cases and $25 \%$ of all adult cases (Pui et al., 2004). T-ALL may arise from any stage of the thymic development of T-cells. Malignant transformation from thymic progenitors into TALL is caused by a variety of mutational and cytogenetic alteration that all corroborate to produce a block in T-cell development while maintaining the highly proliferative state inherent to the process. The major pathway targeted is $\mathrm{NOTCH}$ with more than $50 \%$ of all T-ALL harbouring activating NOTCH mutations (Weng et al., 2004) that often co-occur with deleterious mutations to cell cycle checkpoint enzymes such as $C D K N 2 A$ (Van Vlierberghe et al., 2013). NOTCH is also the 
target of another common mutation, $F X B W 7$, which impairs the degradation of activated NOTCH (Belver and Ferrando, 2016). T-ALL can be divided into a number of broadly defined subtypes depending on their developmental origin. T-ALL arising from the earliest stages of thymocyte development such as ETP, make up $10 \%$ of paediatric cases (Coustan-Smith et al., 2009) and 40-50 \% of adult cases (Van Vlierberghe et al., 2011). ETP T-ALL has a markedly worse prognosis than other types of T-ALL and in adults harbours mutations more typically associated with myeloid cancers, targeting signalling through $N R A S$ instead of $N O T C H$, as well as epigenetic regulators such as IDHI and $I D H 2$ as well as DNMT3A (Zhang et al., 2012). T-ALL arising from the later stages of thymocyte development, such as the DN and DP stages on the other hand most commonly display NOTCH and CDNK2A mutations as is typical of T-ALL (Belver and Ferrando, 2016).

\section{DNA Methylation in Cancer}

The epigenetic regulators targeted in adult ETP-T-ALL typically are IDH1 and 2 as well as DNMT3A which all are regulators of DNA methylation. The specific targeting of DNA methylation as well as the alteration of methylation patterns is a phenomenon typical of all cancers (Baylin and Jones, 2011). Methylation as a modification of mammalian genomes occurs on cytosine and is in general a marker of inactive chromatin. DNA methylation is added to cytosine by the DNA methyl transferase enzymes (DNMTs). Different DNMTs have context specific functions such as DNMT1, which serves to maintain DNA methylation by adding methylation to hemi-methylated DNA during DNA replication and DNMT3A and $\mathrm{B}$, which adds new methylation to previously unmethylated sites (Jones and Liang, 2009). Conversely, DNA methylation may also be removed by the hydroxylation of methylcytosine $(\mathrm{mC})$ to hydroxylmethylcytosine $(\mathrm{hmC})$ by the Ten elven translocase enzymes (TETs) (Scourzic et al., 2015). DNMT3A and especially TET2 are commonly mutated in T-cell cancers with mutations in TET2 exceeding 60\% in peripheral T-cell lymphomas (Lio 
et al., 2019) and 20\% in adult T-ALL (Marçais et al., 2017) implicating it as a major mutational target in cancer transformation. Cancers with altered DNA methylation patterns usually display global DNA demethylation and promoter hyper methylation (Jones and Baylin, 2002). However, the displayed hypermethylation of promoters mainly occur at genes already silenced before transformation (Sproul et al., 2012) and in spite of intense study the consequence of altered DNA methylation in cancer remains relatively unknown (Baylin and Jones, 2011).

\section{The Breakdown of T-cell tolerance and autoimmunity}

While the initiating event in autoimmune disorders is in most cases unknown, the detection of autoreactive T-cells does imply that a breakdown in self-tolerance is partially to blame. Tolerance in T-cells is controlled both centrally through the negative selection of autoreactive T-cells in the thymus and in the periphery through immunosuppression by Tregs. Central tolerance is mainly meditated by the mTECs cells in the medulla which express a large repertoire of peripheral tissue antigens (PTAs), such as insulin, typical of distinct cell types (Cheng and Anderson, 2018; Yang et al., 2015). This expression of PTAs in mTECs is vital to self-tolerance as can be seen by the development of autoimmunity in mice knockout models of Aire (Cheng and Anderson, 2018), one of the master regulators of PTA expression in mTECs, as well as in patients with mutations in Aire (Husebye et al., 2009). This selection process serves both to eliminate potentially autoreactive $\mathrm{T}$ cells through negative selection but also to positively select autoreactive T-regulatory cells to supress autoimmunity in the periphery, commonly known as natural Tregs (nTreg) (Josefowicz et al., 2012). While these central control mechanisms are vital, studies in mice have shown that there is significant leakage of autoreactive cells into the periphery and auto-reactive CD8 and $\mathrm{CD} 4^{+} \mathrm{T}$-cells as well as autoantibody producing B-cells can be found in healthy individuals (Theofilopoulos et al., 
2017). As such, peripheral tolerance is vital to maintaining tissue homeostasis and prevent autoimmunity.

As outlined, there are several peripheral control mechanisms in place to control T-cells responses such as anergy and active suppression by Tregs. Normally, in the absence of stimulatory signals, co-stimulatory molecules such as CD80 or CD86 are absent or very lowly expressed on APCs. As such, autoreactive binding events will lead to anergy rendering the T-cell unresponsive. Anergy however is not a permanent state and can be reversed by stimulatory conditions such as in the event of an infection (Schwartz, 2003). A reduced dependence on costimulation for T-cell activation has been implicated in autoimmune disease as can be seen by the increased disease risk granted by single nucleotide variants (SNPs) in and surrounding the CD28 locus (Esensten et al., 2016, p. 28). In addition, autoreactive T-cells isolated from MS patients could be less dependent on co-stimulation (Cao et al., 2015). Similarity, TCR or MHC (HLA) variants that alter the threshold of activation may also causes disease as can be seen by the fact that variations in HLA is the single largest genetic determinant of disease risk in MS (Wang et al., 2020). Additionally, co-inhibition by Treg cell through the binding of co-inhibitory molecules, such as CTLA4, to the APC are vital to prevent autoimmunity. This is well illustrated in the case of immune-checkpoint therapy where blocking of CTLA4 invokes an immune response towards cancer. As a side effect this may cause widespread autoimmunity with a common side effect being the development of type 1 diabetes (Adams et al., 2016).

\section{Endocrine influence on autoimmunity}

An observation that has been made in autoimmune disorders is that there is a sex imbalance in disease incidence with the majority of autoimmune disorder being more common in women (Amur et al., 2012). This has been attributed to differences in gonadal hormones between the sexes. Especially both estrogen and progesterone have been implicated and shown to have significant immunomodulatory effects 
(Mohammad et al., 2018; Shah et al., 2019). This is most clearly illustrated in several autoimmune disorders such as MS and RA where during pregnancy the increase in progesterone and estrogen concentration in the blood correlates with a temporary reduction in disease severity followed by an increase in severity post-partum as hormone levels dip (Confavreux et al., 1998; Förger and Villiger, 2020). Pregnancy has however also been show to increase disease severity in certain autoimmune disorders such as Systemic lupus erythematosus (SLE) (Moroni and Ponticelli, 2016) and myasthenia gravis (Ferrero et al., 2008). These effects of pregnancy have been suggested to depend on progesterones dampening effect on $\mathrm{T}$-cell responses as well as its ability to promote a skewing of T-cell differentiation towards Th2 and Treg over Th1/17 (Shah et al., 2019).

\section{Th1 in Multiple sclerosis and Rheumatoid arthritis}

MS and RA are both diseases that have traditionally been considered as Th1 dominated (Chemin et al., 2019; Sospedra and Martin, 2005). In MS, this view originates from observations made in the murine model of MS, experimental allergic (autoimmune) encephalomyelitis (EAE), were the secretion of IL-12 by immune cells in the central nervous system and the development of IFN- $\gamma$ producing myelin reactive $\mathrm{CD}^{+}$ T-cells is vital to the disease course (Hafler, 2004; Sospedra and Martin, 2005). However, IL-17 has also been implicated as vital to the disease course of MS and it is currently unclear if MS is a mainly Th1 or Th17 mediated disease (Baecher-Allan et al., 2018). Similarly, in RA, CD4 ${ }^{+}$ T-cells expressing IFN- $\gamma$ were initially isolated from the synovial fluid of patients and the production of IFN- $\gamma$ was shown to be tied to the course of the disease. However, following the discovery of Th17 as a subset, IL-17 producing cells were isolated as well complicating the picture RA (Chemin et al., 2019). 


\section{$\underline{\text { Aims }}$}

The general aim of this thesis was to study T-cells and use their differentiation towards Th1 as a model to discover disease regulators, treatments and biomarkers. More specifically, we aimed to use multiomic information of Th1 differentiation and corroborate findings from different types of omics to gain novel insights.

\section{Specific aims}

- The aim of paper I was to study TET2s importance to paediatric T-ALL and evaluate its potential as a biomarker of treatment sensitivity.

- The aim of paper II was to study the effects of P4 on $\mathrm{CD}^{+} \mathrm{T}$ cell activation and evaluate if $\mathrm{P} 4$ induces immunomodulatory effects consistent with the pregnancy related improvement of MS.

- The aim of paper III was to develop a method to corroborate results between RNA-seq and proteomics of Th1 differentiation and evaluates its potential to improve disease gene predictions and the discovery of biomarkers.

- The aim of paper IV was to further expand on paper II by investigating the effects of $\mathrm{P} 4$ on Th1 differentiation.

Additionally, we aimed to combine ATAC-seq and RNA-seq to investigate chromatin gene interactions during Th1 differentiation and how these were influenced by $\mathrm{P} 4$. 
Olof Rundquist 


\section{$\underline{\text { Study and Experimental design }}$}

\section{Overview}

Throughout my papers, several methods focusing on the study of T-cells were applied and shared, with minor variations, across multiple papers. As the main focus of my $\mathrm{PhD}$ was sequencing methods and their analysis, they will form the focus of this methods section. For a more detailed description of the exact procedures for each paper, please see the associated paper.

\section{T-helper 1 cell differentiation}

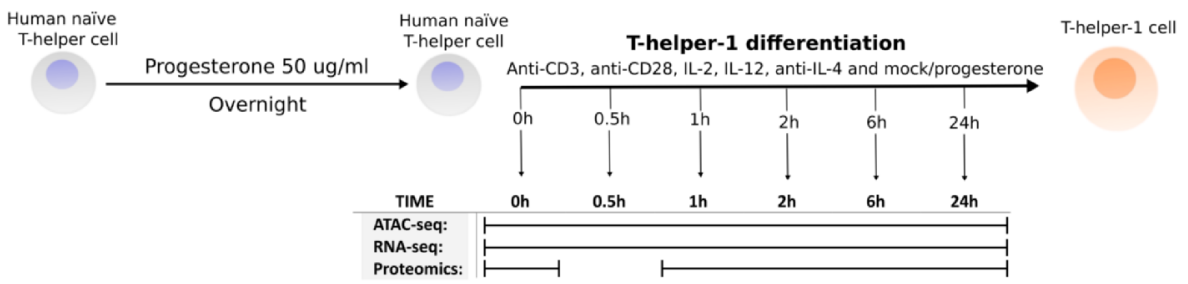

Figure 5: Overview of the Th1 time series. For the Th1 time series we differentiated naïve T-helper cells into T-helper-1 (Th1) cells and performed ATAC-seq (paper IV), RNA-seq (paper III and IV) and Proteomics (paper III). For paper IV the addition of progesterone to the Th1 differentiation reaction as well as the pre-incubation with progesterone was implemented.

\section{Time series design and methodological consideration for Th1 differentiation}

In paper III we devised a time series analysis of early Th1 differentiation encompassing the time points $0,0.5,1,2,6$ and 24 hours. To this time series we then later applied RNA-seq (paper III and IV), ATAC-seq (paper IV) and proteomics (paper III) to gain a holistic understanding of the system (Figure 5). Due to an expected time delay between the expression of mRNA and the production of a protein the $0.5 \mathrm{~h}$ time point was excluded from the proteomics. 


\section{Olof Rundquist}

The aim of this time series was to study gene regulation during Th1 differentiation at an early time point. As such, in order to establish the earliest possible detection point for RNA-seq, we performed qPCR of the key Th1 genes IFNG and IL2 to determine when these were first expressed. This showed these genes to be significantly upregulated at $0.5 \mathrm{~h}$ setting it as the first time point for the system (Figure 6A). To facilitate an instantaneous and even activation of the T-cells Dynabeads ${ }^{\mathrm{TM}}$ Human T-Activator CD3/CD28 were used to provide the $\mathrm{T}$-cell activation signal. Traditionally the $\mathrm{T}$-cell activation signal is provided by plate-bound CD3/CD28 antibodies, as we did in paper II. However, this requires the cells to sink to the bottom of the plate first which leads to a cell specific delay in activation (Figure 6B). In paper II, since the first assayed time point was $6 \mathrm{~h}$ this delay was insignificant but in paper III/IV it would have introduced considerable technical noise to the first time point ( 0.5 hours). This does produce an inherent difference between the activation provided in paper II and III/IV though as in paper II the amount of plate-bound antibody was titrated to provide a medium to weak stimulatory signal. This is not possible with beads as each bead provides the signal of activation in a one bead to one cell ratio and therefore reducing the number of beads would only reduce the number of activated cells rather than the activation strength (Figure 6B and $\mathbf{C}$ ). 

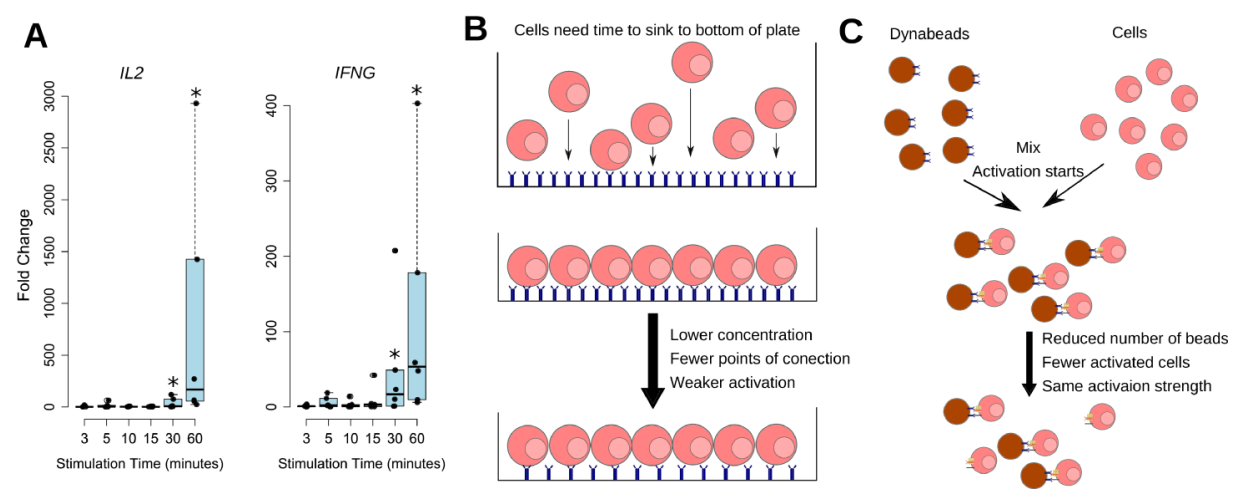

Figure 6: A: QPCR result for $I L 2$ and $I F N G$ for the choosing of the earliest possible time point. B and C: Schematic representation of Th1 stimulation method including impact of timing and antibody concentration for plate-based (B) and bead-based (C) stimulation.

\section{ATAC-seq}

Assay for Transposase-Accessible Chromatin using sequencing or ATAC-seq for short was developed relatively recently in 2013 as a faster and more sensitive approach for the study of chromatin accessibility as compared to previous methods (Buenrostro et al., 2013) such as DNase-seq (Song and Crawford, 2010) and Faire-seq (Simon et al., 2012). Chromatin accessibility as feature of the genome is a measurement of how accessible the DNA strand is to the interaction of proteins such as RNA-polymerase or transcription factors. DNA is in the cell wound around proteins called histones in a structure known as a nucleosome. DNA together with these proteins is referred to as chromatin. Nucleosome density along the DNA-strand may vary and depending on this density the chromatin is divided into eu- and heterochromatin, with euchromatin referring to open regions of the genome with low nucleosome density and likely active transcription and heterochromatin referring to areas of high nucleosome density and likely no transcription. ATAC-seq relies on the use of the hyperactive Tn5 transposase enzyme, which is capable of fragmenting these open regions of the chromatin and simultaneously add sequencing adapters to them, a process referred to as tagmentation (Adey et al., 2010; Goryshin 


\section{Olof Rundquist}

and Reznikoff, 1998, p. 5). These fragments are then sequenced effectively allowing us to map the open regions of the chromatin.

Since the development of the original ATAC-seq method several improvements have been made to the protocol resulting in the development the Fast-ATAC-seq method (Corces et al., 2016) which was then further expanded on with the development of the OmniATAC-seq method (Corces et al., 2017). These improvements have been in the addition of multiple detergents to aid permeabilization of the cell membrane thereby expanding its use to cell types more resistant to lysis, as well as reducing the contribution of reads from the mitochondria to the total number of reads. The mitochondrial genome is not packaged on histones like the rest of the genome and as such would produce a large number of unspecific reads. Traditionally, these reads are ignored in the subsequent analysis but as they may make up a large portion of the sequenced reads, they effectively reduce the sequencing depth increasing the cost of the experiment (Corces et al., 2017). Due to these successive improvements, we decided to use the Omni-ATAC-seq protocol over the original ATAC-seq protocol for our ATAC-seq in paper IV. An overview of the ATAC-seq sample and library preparation is presented in Figure 7. 
A

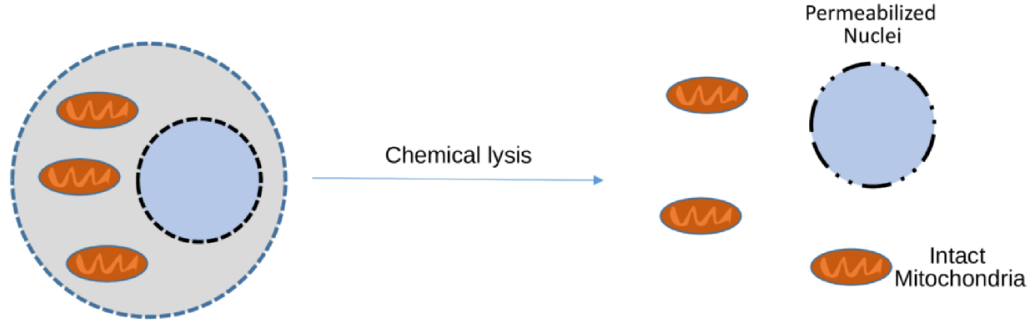

B

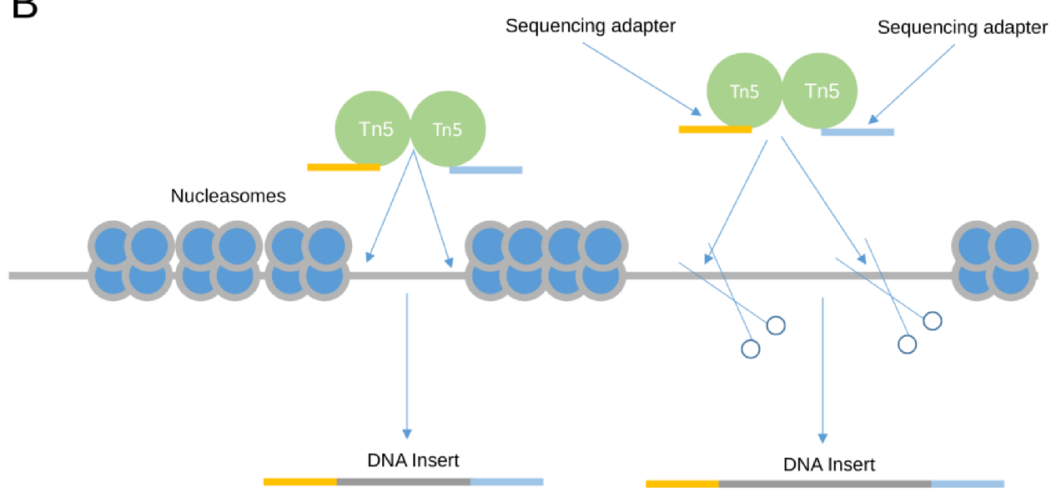

C

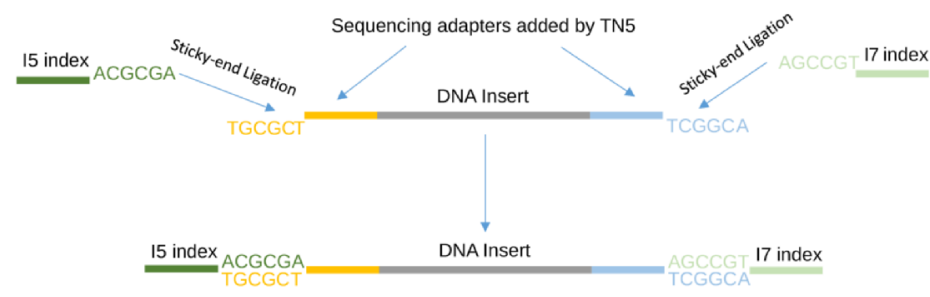

PCR

$5-10$ cycles

15 index

DNA Insert

17 index

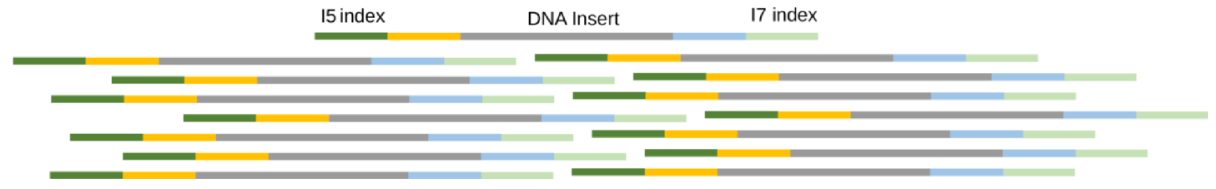

Figure 7: Overview of ATAC-seq sample and library preparation: A:

Chemical cell lysis and permeabilization of the nuclei to enable Tn5 access to the DNA. Mild denaturing conditions keeps the mitochondria intact making its genome unavailable to the Tn5 (Corces et al., 2017). B: Transposition with 


\section{Olof Rundquist}

Tn5 transposase. C: Indexing and amplification of inserts after Tn5 transposition to create the sequencing library.

\section{RNA-seq}

Ribonucleic Acid sequencing (RNA-seq) as a method involves the sequencing of the RNA within a given sample.

In paper I, as we wished to assess the expression of retro-transposons following the treatment with vitamin $\mathrm{C}$ and decitabine we employed total RNA-seq. Total RNA-seq aims to sequence the totality of RNA within a sample and as such employs random hexamer probes to evenly amplify all RNA molecules. However, as the ribosome is partiality made of RNA and ribosomal RNA (rRNA) makes up the majority of the RNA in the cell and is usually not the target of study it must be removed prior to sequencing. As such, total-RNA-seq employs the use of rRNA depleting techniques such as rRNA binding probes to deplete rRNA prior to sequencing. In paper II-IV we employed mRNA-seq to measure the expression of messenger RNA (mRNA) from genes. mRNA-seq involves the use of poly-dT probes to enrich the sample for mRNA by binding to its poly-A tail prior to sequencing, avoiding the issues of rRNA contamination. Total RNA-seq was required in the case of paper I as the majority of retrotransposon transcripts have undergone significant mutational decay, which may have affected their rate of polyadenylation (Paces et al., 2002). The Beijing Genomics Institute (BGI) performed the RNA-seq library preparation and sequencing in paper I, III and IV. The RNA-seq in paper II was performed by the National Genomics Infrastructure (NGI), part of SciLifeLab Sweden. 


\section{Bioinformatics analysis}

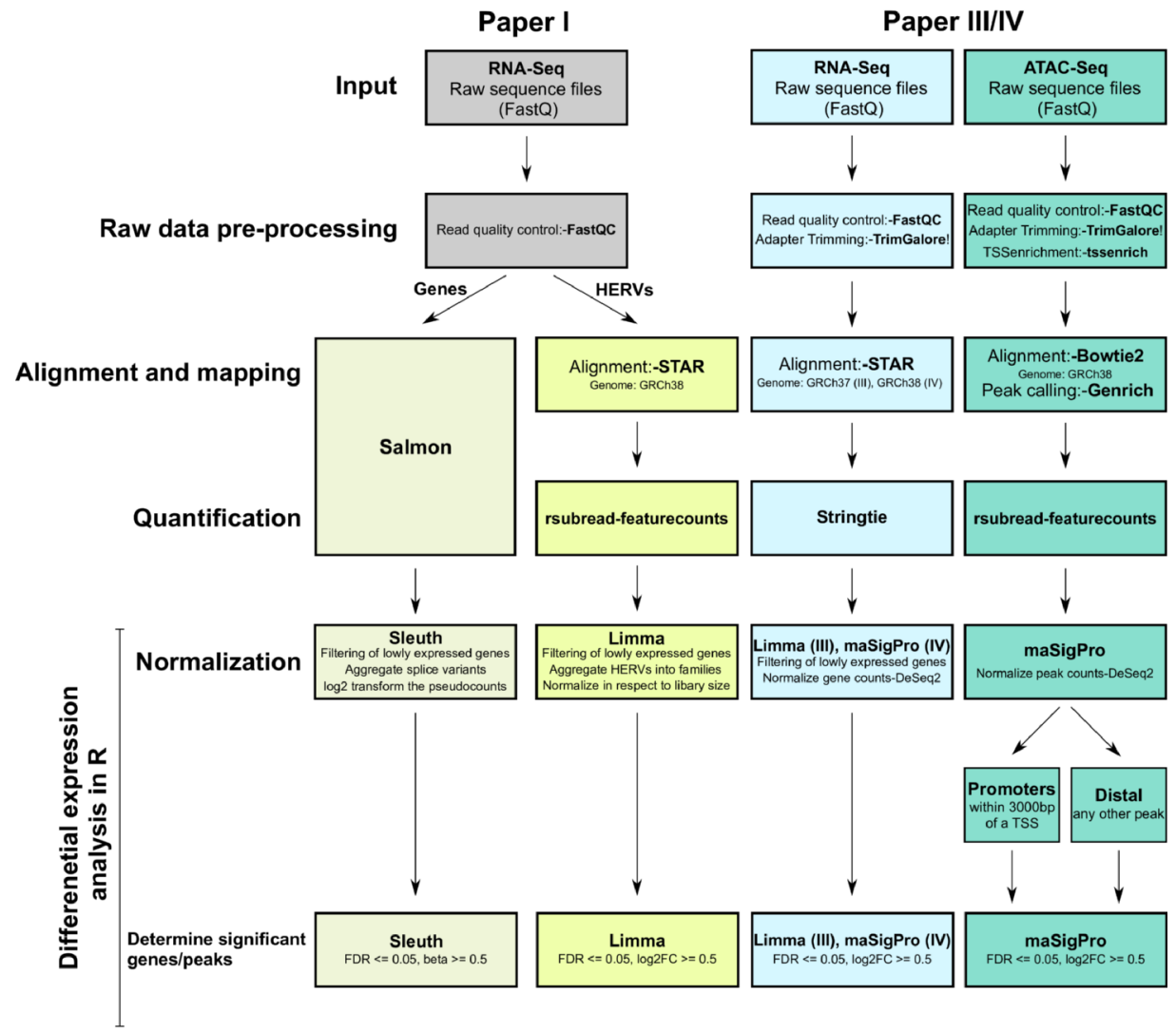

Figure 8: Overview of the bioinformatics analysis pipeline applied in paper I, III and IV.

\section{ATAC-seq pre-processing and methodological considerations}

ATAC-seq data shares many similarities with the ChIP-seq and DNaseseq and the pre-processing of the data as such shares many of the steps of ChIP-seq analysis involving the alignment of reads to the genome, followed by peak calling and the detection of transcription factor motifs. Consequently, many of the tools for analysis are shared but there are specific biases to consider when dealing with ATAC-seq (Yan et al., 2020). 
Prior to sequencing, ATAC-seq library quality was assessed using a fragment analyser. The transposase for ATAC-seq produces a certain spectrum of fragment sizes corresponding to the nucleosome regions of the genome. Each nucleosome is approximately $200 \mathrm{bp}$ long and as such a periodic pattern of peaks at every $200 \mathrm{bp}$ should be observed corresponding to mono, di, tri and higher order nucleosomes (Buenrostro et al., 2013; Yan et al., 2020).

In ATAC-seq paired end sequencing is preferred over single end sequencing as it allows direct estimation of the size of the fragments generated from the transposition reaction, usually referred to as insert size. As such, we employed paired -end sequencing with a read length of $150 \mathrm{bp}$ for the ATAC-seq. The sequencing was performed by the National genomics institute of Sweden (NGI) using an Illumina 6000 NovaSeq instrument. Sequencing quality was assessed with Fastqc and through calculating the transcription start site (TSS) enrichment score for each sample with tssenrich. As the promoters of actively transcribed genes are expected to be open, ATAC-seq should give a clear enrichment of reads over TSS regions. Proper insert size distribution after sequencing was also confirmed by counting the length of each insert, with a combination of samtools view and awk, and then plotting a histogram over the resulting insert sizes using pyplot in python. The sequence read alignment for the ATAC-seq was carried out with Bowtie2. An overview of the ATAC-seq pre-processing is available in the rightmost part of Figure 8.

\section{ATAC-seq peak calling and quantification}

There are very few peak callers developed specifically for ATAC-seq and the majority of studies rely on the use of macs2, a tool for ChIP-seq, to call peaks (Yan et al., 2020). However, macs2 requires significant parameter adjustment for its use in ATAC-seq and there is a lack of consensus on what parameters to use (https://informatics.fas.harvard.edu/atac-seq-guidelines.html). As such 
we used Genrich, a tool in development for ATAC-seq by the Harvard institute, to call peaks (https://github.com/jsh58/Genrich). To achieve a set of highly reproducible peaks, we called peaks for each sample individually and overlapped the peaks with bedtools multiintersect. Only regions called as peaks in at least 2 out of 3 replicates for each time point were kept for further analysis. Peaks within less than $150 \mathrm{bp}$ (read length) from each other were then merged with bedtools merge, generating the consensus peak set which was used for further analysis.

Read counts in peaks were then quantified using featurecounts from Rsubread. Prior to the counting of reads in peaks all alignments were shifted with alignmentSive --ATACseq shift from deeptools to account for the cleavage bias presented by Tn5 transposases in order to facilitate downstream footprinting analysis (Buenrostro et al., 2013). This was not necessary prior to peak calling as Genrich performs this shift internally. 


\section{The calling of Transcription factor footprints and the matching of motifs}

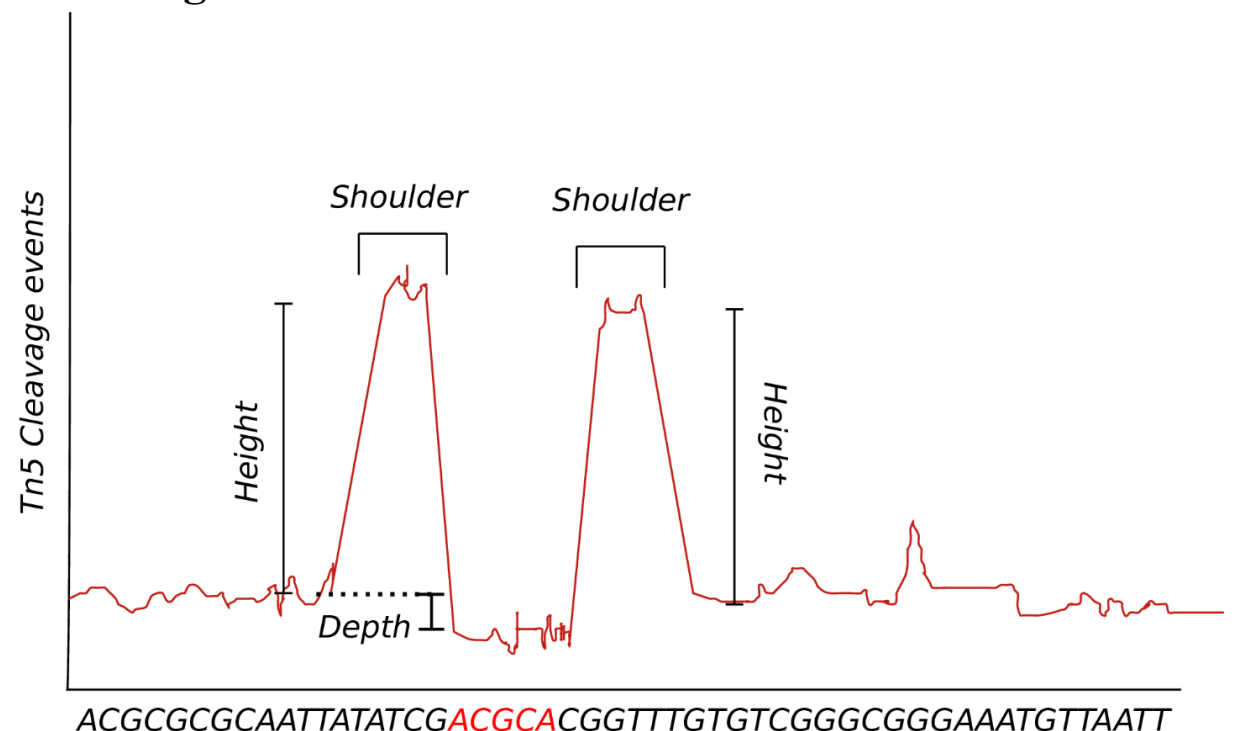

Binding Site

Figure 9: Illustration of an idealized TF footprint. TF footprints are detected as short areas of lower signal surrounded by shoulders of higher signal. From this, several parameters can be isolated for downstream analysis such as the height of the shoulders and the depth of the footprint as well as the binding site sequence.

To analyse gene and transcription factor (TF) interactions in paper IV, we applied TF footprinting to our ATAC-seq data to look for potentially bound TF binding sites in our peaks. TF footprinting is based around the concept where a protein binding to the DNA confers protection against enzymatic cleavage of the bound DNA resulting in a dip in cleavage events in the bound area allowing us to detect protein DNA binding events (Galas and Schmitz, 1978; Vierstra and Stamatoyannopoulos, 2016) (Figure 9). DNA footprinting tools can be divided into de novo and motif-centric tools. De novo tools aim to find all possible binding events based on the features of a typical footprint, while motif-centric tools use prior TF binding site information to predict binding events (Yan et al., 2020). Motif-centric tools, however, due to the requirement of prior knowledge about TF binding lack generalizability as they are 
dependent on the system they were trained on and our limited repertoire of studied TFs (Yan et al., 2020). We used the pyDnase workflow (https://pythonhosted.org/pyDNase/tutorial.html) with wellington algorithm (Piper et al., 2013), a de novo method, for footprinting followed by motif matching of said motifs with Homer (Heinz et al., 2010).

To facilitate footprinting with Wellington we performed the shifting of reads, with +4 on the positive strand and -5 on the negative strand, as recommended by the original ATAC-seq paper to account for Tn5 cleavage bias (Buenrostro et al., 2013). Recently, a number of articles have been published stating that this type of bias correction is not sufficient to properly correct for Tn5 cleavage bias and released footprinting tools to incorporate additional parameters for bias correction such as Tn5 binding site preference (Li et al., 2019; Martins et al., 2018; Yan et al., 2020). However, until very recently there was not a unified workflow to implement this bias correction (Bentsen et al., 2020).

\section{RNA-seq pre-processing and methodological considerations}

Similar to the ATAC-seq, read quality control and the trimming of sequencing adapters was performed with fastQC and TrimGalore for the RNA-seq (Figure8). TrimGalore was not used in paper I as the sequencing adapters were removed by the sequencing provider (BGI) prior to the delivery of the data. For alignment of reads the splice aware aligner STAR (Dobin et al., 2013) was used in paper III and IV. As we desired to construct splice variant based model of mRNA to protein expression in paper III, we then used Stringtie for accurate splice variant quantification (Pertea et al., 2015).

In paper I we used Salmon (Patro et al., 2017), a non-alignment based method, for the direct quantification of gene expression from reads. Non-alignment based methods rely on the use of a predefined database 
of mRNA sequences to directly align sequencing reads to the transcribed mRNA rather than the genome, referred to as pseudoalignment (Bray et al., 2016; Patro et al., 2017, 2014). Similar databases have been constructed for HERVs for the use with non-alignment based techniques (Jeong et al., 2018; Kong et al., 2019; Lanciano and Cristofari, 2020). However, these are limited to only a small subsection of the know HERVs in the human genome. As such, to analyse HERV expression in paper I, we applied STAR to align the reads and used featurecounts from Rsubread with the "-primary" option to only report primary alignments (M. Liu et al., 2016), to quantify the expression of all available HERVs in the HERV database (Paces et al., 2002).

\section{Differential expression analysis}

Depending on the analysis pipeline different methods were applied for differential expression analysis throughout my papers (Figure 8). While the methods varied between the papers, the overall decisions and considerations remained similar. Differential expression analysis involves the testing of tens of thousands of genes simultaneously. As such, it is important to minimize the number of tests and account for false positives. Therefore, we filtered lowly expressed genes prior to the application of the respective differential expression method and applied Benjamini-Hochberg false discovery rate (FDR) correction.

Additionally, to further minimize the risk of false positives, only genes that changed with a $\log 2$ fold change of at least 0.5 were considered for further analysis. These considerations were also applied to the ATACseq in paper IV and the HERV analysis in paper I. For the HERV analysis, as there are more than 500000 know HERV sites in the genome and the majority are not expected to be expressed (Paces et al., 2002), we merged counts from individual HERVs into families, in accordance with the method described in Liu et al. 2016, prior to the application of the differential expression analysis. 


\section{The integration of ATAC-seq and RNA-seq through correlation}

In paper IV, as we wished to study TF gene interactions we sought to tie the peaks to the respective genes that they regulate. This presented several challenges. If an ATAC-seq peak overlaps the TSS of a given gene it can be reasonably assumed that the peak stems from the promoter of said gene. However, the majority of discovered peaks for ATAC-seq was in intergenic regions and in such a case there is no clear connection from the ATAC-seq data itself for what gene the peak interacts with. T-cells are known to undergo significant chromatin remodelling during differentiation (Yukawa et al., 2020) and as such, established maps are not necessarily useful for the mapping of distal interaction during differentiation. As such, we used the Pearson correlation over time to correlate the relative log2 fold change of peaks to the $\log 2$ fold change of surrounding genes and selected the gene with the highest absolute correlation. Correlation however is not causation and as such to limit the possibility of spurious correlations the genomic range within which the correlations were calculated was limited to 3000 bp for promoter peaks and $100000 \mathrm{bp}$ for distal peaks. This range was based on studies of TF regulatory distance showing that the majority of $\mathrm{TF}$ interactions has been shown to be in the range of 0-100 $000 \mathrm{bp}$ from the TSS (Chen et al., 2020). These correlations were performed for both the P4 treated and non-P4 treated time-series independently and the selection of the gene for each peak was based on the mean correlation of the two time-series. To further limit spurious correlations peak-to-gene interaction that varied greatly between the two time-series were dropped and only genes and peaks that significantly changed (MaSiPro, FDR $<$ 0.05 ) over the time series were kept for further analysis. 
Olof Rundquist 


\section{$\underline{\text { Results and Discussion }}$}

\section{$\mathrm{CD} 4^{+} \mathrm{T}$-cells as a model system}

The process of cellular differentiation is most commonly studied during embryonic development with the aid of animal models. As a consequence, the embryonal process of differentiation and its factors are quite well known in animals. These cells however are generally not available from humans due to ethical concerns and as such, one must turn to other cell types to study differentiation in humans. Most tissues in the human body are primarily made up of terminally differentiated cells, i.e., cells that have passed through all steps of differentiation. The adaptive immune system however is a notable exception as it needs to be able to react to external factors and therefore maintains a repertoire of non-terminally differentiated cells. Among these, nTh cells are relatively unique in their ability to differentiate into multiple subtypes. As such, nTh cells present a unique opportunity to study the process of cellular differentiation in humans.

As such, the study of T-cells formed the core of this thesis from start to finish. In paper I, we studied T-cell methylation dynamics in the context of T-cell acute lymphoblastic leukaemia (T-ALL). In paper II, we studied T-cell activation in the context of multiple sclerosis (MS) and finally in paper III and IV we studied Th1 differentiation with multiple types of omics and connected the results back to the results on T-cell activation in MS. 


\section{TET2 in T-ALL (Paper I)}

\section{Pediatric T-ALL as a disease}

Pediatric T-ALL is a disease that stems from a failure of T-cell maturation. T-ALL may arise from any stage in the development from $\mathrm{T}$-cell progenitors to single positive T-cells with the earliest forms arising from the ETP state generally considered the most severe. Since the 1970 s the survival rate of T-ALL has gradually increased from around $50 \%$ to $75 \%$ in the year 2000 . This rate of improvement has however slowed down in recent years and the survival rate for relapse cases remains a dismal 25\% (Schmiegelow et al., 2010). Most of the gain in recent years has been achieved through increasing the intensity of chemotherapy regimes but this gain has not come without cost as treatment related toxicity has increased and with it, severe to lethal side effects (Ness et al., 2011). There is therefore a great need for new treatments that not only increase survival but also reduces toxicity in $\mathrm{T}$ ALL.

\section{TET2 is frequently silenced in $\mathbf{T}-\mathbf{A L L}$}

While mutations have been reported to occur in $20 \%$ of adult cases of T-ALL (Marçais et al., 2017), TET2 has not previously been implicated as a major mutational target in pediatric T-ALL. Indeed, through a systematic meta-analysis of targeted exome, whole exome, and whole genome sequencing data of leukemic blast cells from 854 patients (paper 1, data S1) we determined TET2 mutations to be rare at $0.7 \%$. Additionally, mutations in the isocitrate dehydrogenase genes (IDH1 \& IDH2), that may phenocopy TET mutations through producing an inhibitor of the enzymes, were similarly low at $1.9 \%$ (Figure 10A). However, further study of TET2 expression in public RNA-seq and DNA methylation data of both primary leukemic blasts and cell lines showed that TET2 was frequently repressed or silenced in T-ALL and that this repression was associated with the methylation of the TET2 
promoter (Figure 10B-F). This establishes TET2 as a major target during the development of T-ALL and as a possible treatment target.
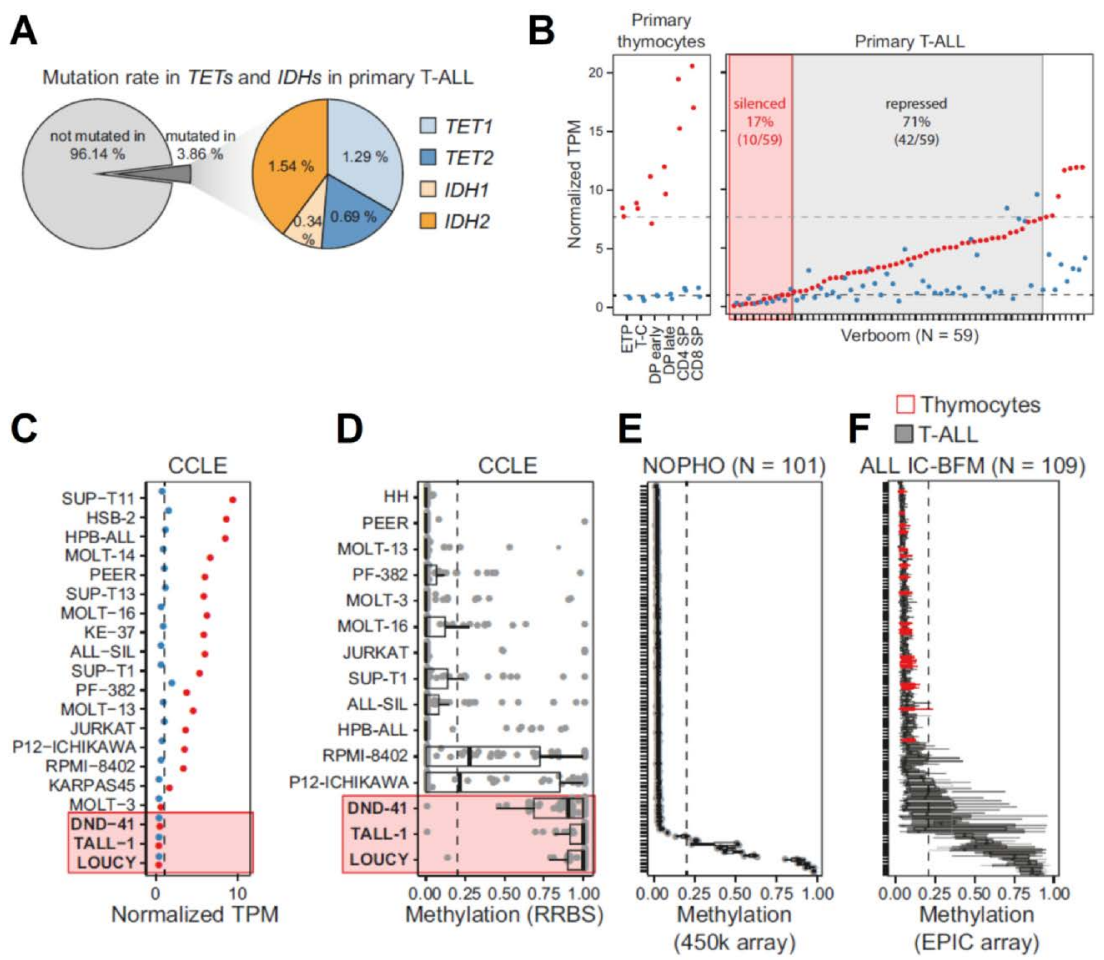

Figure 10: TET2 as a tumor suppressor in T-ALL: A: Mutations in TETs and IDHs in primary human T-ALL from a meta-analysis of nine studies including 854 patients. B: Expression of TET2a (red) and TET2b (blue) in the 6 human thymocyte subtypes (Left) and 59 primary T-ALL patients (Right). Dotted black line: silenced TET2 $($ TPM $<1)$, gray dotted line: repressed TET2 (one-sample t test, $\mathrm{P}<0.05$, compared to ETP, T-C, and DP primary thymoctes). T-C, T cell-committed (equivalent to DN); DP, double positive. C: TET2 expression in T-ALL cancer cell lines based on RNA-seq data from Broad Institute CCLE. D-F: Methylation of the TET2 promoter (D) in T-ALL cell lines based on RRBS from CCLE and in primary human T-ALL patients from $(\mathbf{E})$ NOPHO and (F) the ALL IC-BFM protocol including 20 samples from healthy human thymocytes (red). C: Dotted black line at TPM $=1$ as cutoff for silencing. D-F: Dotted black line at methylation $=0.2$.Vitamin $\mathrm{C}$ as a co-factor of TET 2 and its potential as a treatment of cancer 
A major co-factor of the TET enzymes is Vitamin C (Wu and Zhang, 2017). Vitamin $C$ has a long and troubled history as a cancer treatment. Originally suggested and championed by Linus Pauling as a potential anti-cancer agent in the 1970s (Cameron and Pauling, 1978) Vitamin C was deemed ineffective in treating cancer following third stage clinical trials by the Mayo clinic in the 1980s (Creagan et al., 1979; Moertel et al., 1985). A major difference, however, between the work of Linus Pauling and the later clinical trials was in the administration of Vitamin $\mathrm{C}$ as a treatment. In the studies by Linus Pauling Vitamin $\mathrm{C}$ was given intravenously while in the clinical trials vitamin $\mathrm{C}$ was administered orally (Padayatty et al., 2004). In 2004 through studies of the metabolism of Vitamin $\mathrm{C}$ it was shown that there was a limit to how much Vitamin $\mathrm{C}$ could be absorbed through the digestive system effectively capping orally given vitamin $C$ blood values at $0.2 \mathrm{mM}$ while intravenous administration could consistently achieve concentrations exceeding $10 \mathrm{mM}$ (Padayatty et al., 2004). This caused vitamin $\mathrm{C}$ to once again be re-considered as a possible anti-cancer agent. Vitamin $\mathrm{C}$ has several advantages in theory to traditional chemotherapy, as it is non-toxic and does not produce long-term side effects (Agathocleous et al., 2017; Cimmino et al., 2017; Rivers, 1987).

Three pathways have been suggested as potential avenues through which Vitamin C may present a cytotoxic effect on cancer cells. The first is through the production of reactive oxygen species (ROS), mainly hydrogen peroxide. Vitamin $\mathrm{C}$ is most well known as an anti-oxidant, in essence an agent that prevents the formation of ROS, but can at high concentration autoxidize through fenton-chemistry and produce ROS (Chen et al., 2005; Prousek, 2007). ROS are highly damaging to cells and are known to cause apoptosis (Ueda et al., 2002). The production of high concentrations of ROS is common in cancer due to the high metabolic activity usually displayed by cancer cells and as such in theory; they are more vulnerable to it than normal functioning cells. The second mechanism is through starvation of ATP. Vitamin C, also known as ascorbic acid, in solution is unstable with a half-life of 10-15 minutes 
at room temperature, and degrades to dehydro-ascorbic acid (DHA). DHA is taken up by cells through the Glut family of transmembrane transporters and may be used to produce new vitamin $\mathrm{C}$ by the protein $\mathrm{GSH}$. This process can at high concentration of DHA in cancer cells, with metabolic aberrations due to mutations in $K R A S$ and $B R A F$, lead to $\mathrm{NAD}^{+}$depletion and subsequent starvation of ATP and cell death (Yun et al., 2015). Thirdly and finally, Vitamin $C$ has been suggested to compensate for the lack of a given TET enzyme, most often TET2, by its co-factor activity increasing the activity of the remaining TET enzymes which in theory would restore normal cell methylation patterns and potentially cause apoptosis (Agathocleous et al., 2017; Cimmino et al., 2017) (Figure 11A).

As our initial experiments had shown that high concentrations $(>=3 \mathrm{M})$ Vitamin C were highly toxic to our cancer cell lines (Figure 11B) we set out to test which of the above mechanisms were causative. Through systematic testing of each mechanistic pathway, we showed that the addition of toxic levels of Vitamin $\mathrm{C}$ to cell lines increased intra and extracellular ROS and that the toxicity could be rescued through the addition of catalase to remove said ROS (Figure 11C-E). This provided strong support for ROS as the causative agent in our cell lines. Additionally, treatment with non-toxic doses of Vitamin $\mathrm{C}$ significantly (P-value) increased genome wide levels of 5-hmC implying that this effect in itself was not toxic (Figure 11F). Finally, through blocking the transport of Vitamin C and DHA across the cell membrane with phloretin we showed that the observed toxicity did not require transport across the cell membrane effectively ruling out an intra-cellular mechanism of action (Figure 11G). As such we could conclude that the observed toxicity of Vitamin C was completely independent of its influence on the TET enzymes in T-ALL. 
A

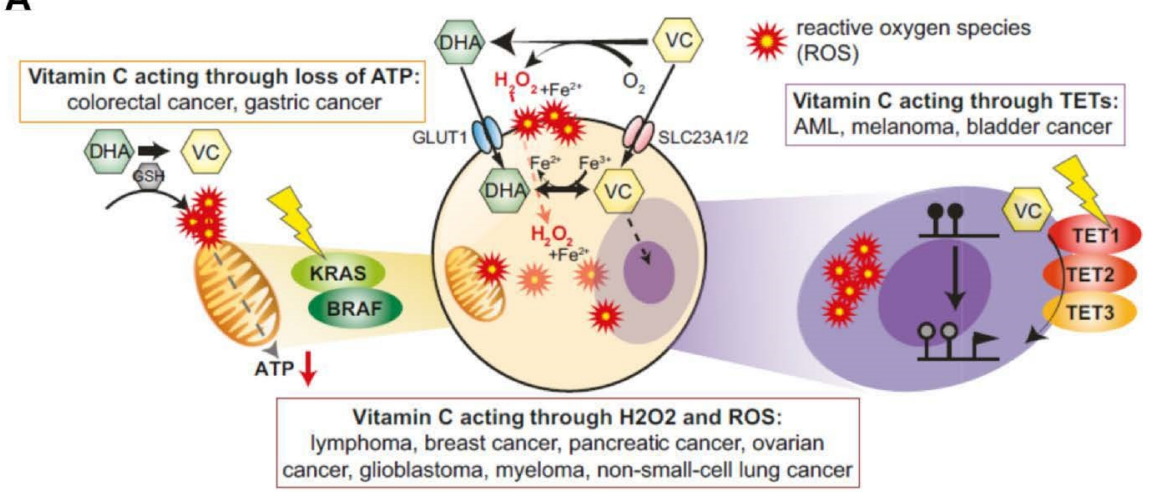

B

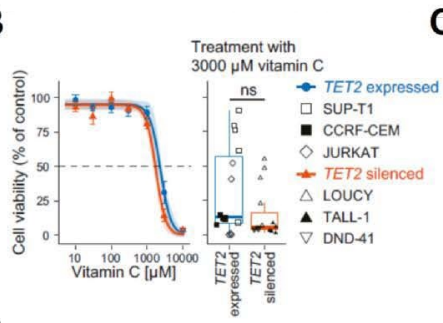

$E$
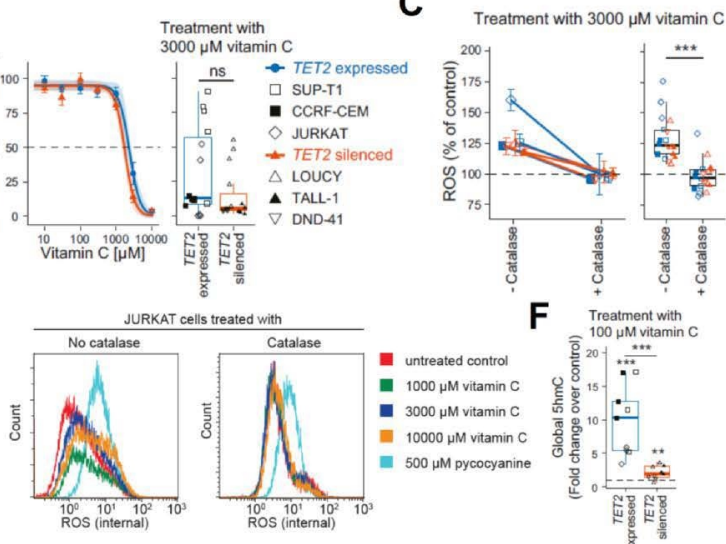

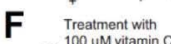
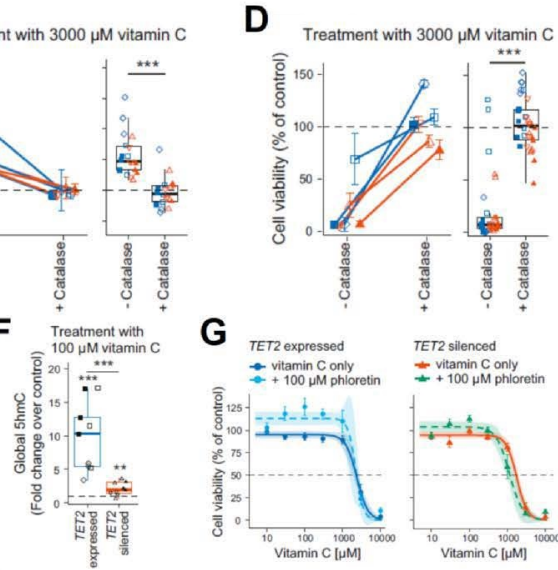

Cell Lines TET2 expressed aSUP-T1 $₫$ CCRF-CEM $\diamond$ JURKAT TET2 silenced $\triangle$ LOUCY $\triangle$ TALL-1 $\nabla$ DND-41

Figure 11: Cytotoxicity of vitamin C (VC) is caused by ROS independently of TET activity in vitro: A: Treatment with VC can mediate its cytotoxic effect through three main pathways: 1) production of hydrogen peroxide $\left(\mathrm{H}_{2} \mathrm{O}_{2}\right)$ and ROS during oxidation of $\mathrm{VC}$ to DHA, 2) energy crisis in cancers with a $K R A S$ or $B R A F$ mutation (yellow flash) after DHA is reduced back to VC intracellularly, or 3) cofactor of the TET enzymes (TET1-3) leading to increased enzymatic activity. GSH, glutathione. B: Cell viability curve for T-ALL cell lines with expressed and silenced TET2 treated with increasing concentrations of $\mathrm{VC}$ for $24 \mathrm{~h}$ (Left) and boxplot showing cell viability for treatment with $3,000 \mu \mathrm{M} \mathrm{VC}$ compared to untreated control (Right). C: Intracellular and extracellular ROS created in response to treatment of T-ALL cell lines with $3,000 \mu \mathrm{M} \mathrm{VC}$ without and with the addition of catalase for each cell line individually (Left) and box plot representing all cell lines (Right) relative to an untreated control (dotted line). D: Cell viability of T-ALL cell lines after treatment with $3,000 \mu \mathrm{M} \mathrm{VC}$ without and with the addition of catalase for each cell line separately (Left) and all cell lines 
combined (Right). Percentage of untreated control. E: Intracellular levels of reactive oxygen species (ROS) in JURKAT cells treated with indicated levels of vitamin $\mathrm{C}$ in the absence (left panel, two independent replicates) or presence (right panel, one replicate) of catalase as measured by flow cytometry. F: Quantification of signaling intensity comparing cell lines with expressed and silenced TET2 relative to untreated control samples (dotted line). G: Cell viability curves for T-ALL cell lines treated with increasing concentrations of VC with or without $100 \mu \mathrm{M}$ phloretin for cell lines with expressed TET2 (Left) or silenced TET2 (Right). Biological triplicates for three different cell lines each $\left(\mathrm{n}_{\text {expressed }}=9\right.$ and $\left.\mathrm{n}_{\text {silenced }}=9\right) .(\mathbf{C}, \mathbf{D}$ and $\mathbf{F})$ Two-tailed, unpaired Student's t test; ns, $\mathrm{P}>0.05 ; * \mathrm{P} \leq 0.05 ; * * \mathrm{P} \leq 0.01 ; * * * \mathrm{P} \leq 0.001$.

\section{TET2 acts as a marker of sensitivity to the DNA demethylating agent decitabine}

While the effect of Vitamin C on the TET enzymes may not be toxic in and of itself, it does establish vitamin $\mathrm{C}$ as a DNA demethylating agent in T-ALL. Vitamin C has previously been investigated for synergistic effects with other DNA demethylating agents, primarily decitabine (M. Liu et al., 2016; Luchtel et al., 2020). Decitabine, also known as 5azacytidine, is a cytidine analogue and inhibits the maintenance of DNA methylation through incorporating into the genome upon replication and causing the degradation of DNMT1 (Christman, 2002). Therefore, we aimed to investigate if vitamin $\mathrm{C}$ had synergistic effects with decitabine treatment in T-ALL. First through treatment of our cell lines with decitabine we showed that TET2 silenced cell lines were especially sensitive to decitabine (Figure 12A). Implying that loss of TET2 is a marker of decitabine sensitivity in T-ALL. Addtionaly, qPCR showed that treatment with decitabine lead to the re-expression of the normaly methylated genes $G A G E$ and $D A Z L$ as well as restored the expression of silenced TET2 (Figure 12B). 

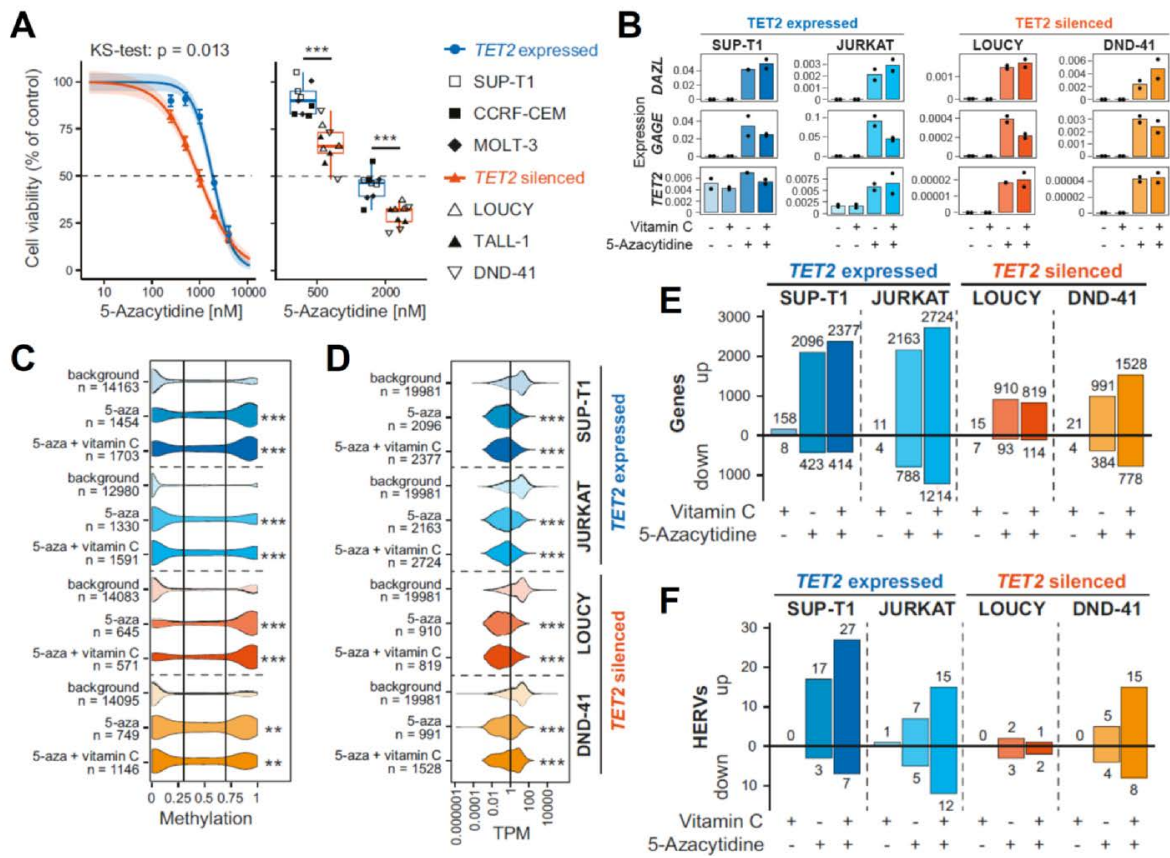

Figure 12: TET2 is a marker of decitabine sensitivity and decitabine acts synergistically with vitamin $C$ to increase expression of methylated genes and HERVs: A: Cell viability curve for T-ALL cell lines with wild-type (3 cell lines) and silenced ( 3 cell lines) TET2 treated with increasing concentrations of 5-aza for $72 \mathrm{~h}$, comparison by Kolmogorov-Smirnov test (Left). Boxplot showing cell viability for treatment with 500 and 2,000 nM 5aza compared to untreated control; two-tailed, unpaired Student's t test; ns, P > $0.05 ; * \mathrm{P} \leq 0.05 ; * * \mathrm{P} \leq 0.01 ; * * * \mathrm{P} \leq 0.001$ (Right). $\mathrm{n}=3$ for each cell line. $\mathrm{B}$ : Expression of TET2 and control genes DAZL and GAGE measured by qPCR relative to housekeeping gene $G A P D H$ in T-ALL cell lines with expressed (SUP-T1, JURKAT) and silenced (LOUCY, DND-41) TET2 after treatment with 2,000 $\mu \mathrm{M}$ 5-Azacytidine and $100 \mu \mathrm{M}$ vitamin $\mathrm{C}$ as indicated for 72 hour. C: Base-resolution promoter DNA methylation in untreated T-ALL cell lines for genes that become up-regulated following treatment with 2,000 $\mu \mathrm{M}$ 5-aza and $100 \mu \mathrm{M}$ vitamin C for $72 \mathrm{~h}$. D: Expression (TPM) in untreated T-ALL cell lines for genes that become up regulated following treatment with $2,000 \mu \mathrm{M} 5$ aza and $100 \mu \mathrm{M}$ vitamin $\mathrm{C}$ for $72 \mathrm{~h}$. E: Number of differentially expressed genes in TET2-expressing and TET2-deficient cells when treated with 2,000 $\mu \mathrm{M} 5$-aza and $100 \mu \mathrm{M}$ vitamin $\mathrm{C}$ for $72 \mathrm{~h}$. F: Number of differentially expressed HERVs [ $\log (2)$ fold change $>0.5$, padjusted $<0.05]$ in TET2expressing and TET2-deficient cells when treated with 2,000 $\mu \mathrm{M}$ 5-aza and $100 \mu \mathrm{M}$ vitamin $\mathrm{C}$ for $72 \mathrm{~h}$. 
Then, using total RNA-seq we investigated expression of genes and retrotransposons (see next section) following decitabine treatment and if there was a synergistic effect with vitamin C. Treatment with decitabine lead to a global increase in gene expression in all treated cell lines with the most significant effect observed in TET2 expressing cell lines (Figure 12E). Additionally, this effect was increased upon the addition of vitamin $C$ (Figure 12E). The upregulated genes by decitabine and vitamin $\mathrm{C}$ were also enriched for genes with high proportions of promoter methylation and genes that were not normally expressed implying the reactivation of normally methylated and silenced transcripts upon treatment (Figure 12C and D). Among these rexpressed genes were TET2 in Loucy and DND41, confirming the results from the qPCR.

\section{The re-activation of retrotransposons as a possible mechanism of treatment}

One of the main functions of DNA methylation is to maintain the repression of transposable elements in the DNA such as retrotransposons. Retrotransposons are short mobile genomic elements and are the remnants of incorporated retroviruses. Overexpression of retrotransposon transcripts has previously been detected in patients and cell lines treated with DNA demethylating agents such as decitabine (Ohtani et al., 2020; Roulois et al., 2015). These transcripts have been shown to have an immunogenic effect (Saini et al., 2020) and have as such been suggested as targets for immunotherapy as well as a biomarker for treatment sensitivity (Ohtani et al., 2020). Indeed, treatment with decitabine in our cell lines resulted in the re-expression of several families of retrotransposons such as HERV-Fc1, LTR12E, MER70A, and MER48 which have previously been reported to be reexpressed following decitabine treatment (M. Liu et al., 2016). Additionally, this effect was significantly enhanced by the addition of $0.1 \mathrm{M}$ vitamin $\mathrm{C}$ supporting its possibly synergistic role in combination with decitabine (Figure 12F). This has not previously been reported in T-ALL and shows that conclusions made regarding the connection 
between decitabine treatment the re-expression of retroviral elements may also be applicable to T-ALL.

\section{Combining omic techniques in T-cells (Paper III and IV)}

As touched upon in this thesis the combination of different omic techniques is not a straightforward process. While ATAC-seq does provide a quantification of the accessibility of a region of the chromatin, implying that the region in question is in use, it does not necessarily provide information on what gene this is significant to. Nor is it know to what degree this quantification i.e., the amount of reads from a given region contributes the expression of said gene. Similarly, with RNA-seq it has been noted that there is a lack of correlation between the amount of transcribed mRNA and the amount of produced protein. This problem of translatability and our attempt to answer it formed the core of paper III, and to a lesser extent paper IV. As such in paper III we sought to construct a model of mRNA expression to protein abundance and apply it for biomarker discovery. Similarly, in paper IV we combined ATAC-seq with RNA-seq through correlation to study the impact of $\mathrm{P} 4$ on Th1 differentiation.

\section{Constructing a model of mRNA to protein abundance (paper III)}

The reasons for the low correlation between mRNA expression and protein abundance stems from multiple sources such as mRNA decay, inefficient translation of the mRNA, unequal contribution of splice variants and post translational degradation (Zhao et al., 2019). A pioneering work was published by (Wilhelm et al., 2014) who through the incorporation of measurements of translation rates was able to achieve high correlations ( 0.9$)$ between predicated protein values and measured values. The usefulness of the Wilhelm approach has however been questioned and there is a current ongoing debate in the field as to 
how to approach the issue (Fortelny et al., 2017; Gry et al., 2009; Y. Liu et al., 2016; Maier et al., 2009; Payne, 2015; Vogel and Marcotte, 2012). The majority of the previous work in this field has however focused on prediction from steady state data. As our data was on a time series this allowed us to study the importance of factors such as time delay and the deep sequencing depth to incorporate splice variant information. Previous time-series studies have been performed on the predication of mRNA to protein abundance, most prominently in yeast (Teo et al., 2014) but to our knowledge our study represents one of the first cases to attempt to construct a model such as this for a primary human cell system.

To start with, we constructed a null model where mRNA gene expression was directly correlated to the protein abundance in order to demonstrate the issue. This, in line with the steady state case, showed a low correlation ( 0.21$)$ between mRNA expression and protein abundance (Fortelny et al., 2017). As our group had previous experience with predictive regularised linear models from short time-series data (Gustafsson et al., 2015; Magnusson et al., 2017) we proceeded to construct a L1 penalized regression model of mRNA splice variant expression to protein abundance over time. This initial model showed a large improvement in correlation from the null model. To further improve our predictions, we then incorporated time delay as a variable in the model by calculating the optimal time delay for each splice variant. This resulted in the final gene specific time delay model with an mRNA expression to protein abundance correlation averaging 0.87 (Figure 13A). We are aware that parts of this is due to the use of more parameters for data-fitting, and this correlation was not independently validated, but we believe that the increase in correlation is needed for the models to be relevant to Th1 differentiation. We then proceeded to validate this modelling approach by repeating it on publicly available RNA-seq and proteomics time series data of mouse B-cell differentiation and human Treg differentiation, once again demonstrating an improvement to the correlation (Figure 13A). 
A

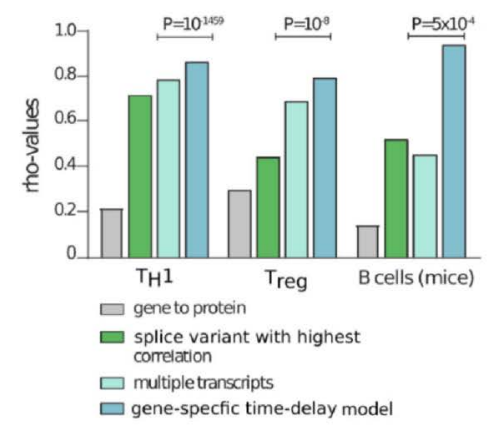

C

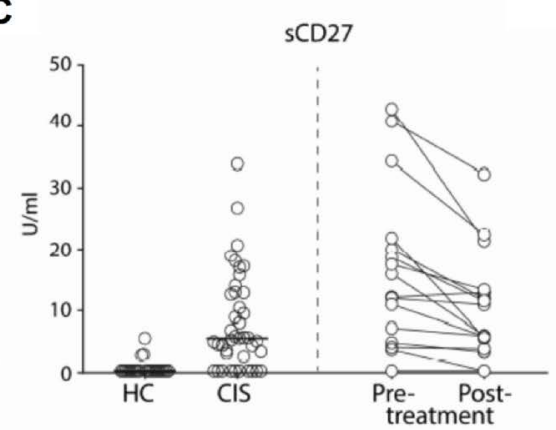

B
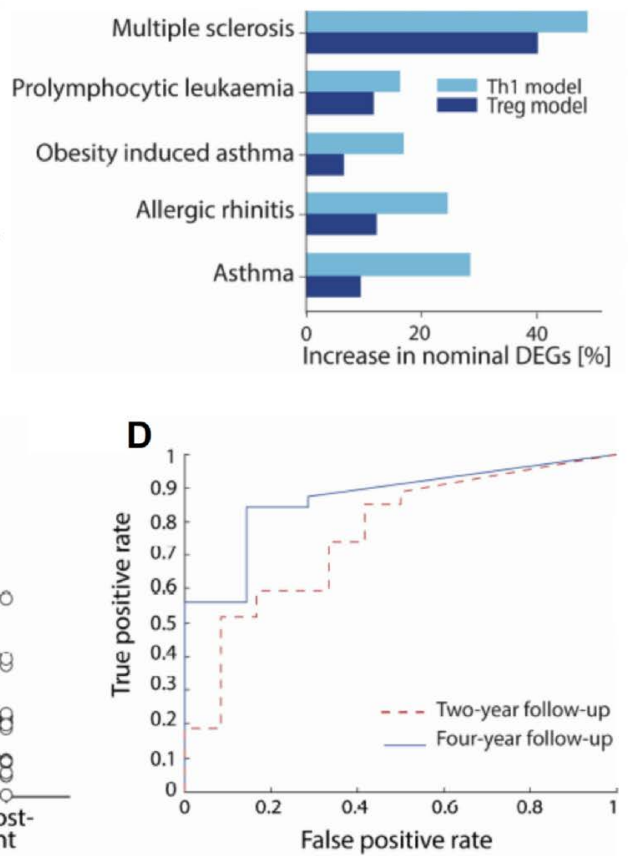

Figure 13: Multiple transcripts and time-delays increased mRNA and protein correlations significantly leading to the discovery of new potential biomarkers of complex diseases that were validated in multiple sclerosis (MS): A: Median correlation coefficients (rho) for different mathematical protein prediction models derived from mRNA with increasing protein abundance correlations. P-values were derived from predictions using leaveone-out cross-validation. B: Differential predicted protein (PP) analysis of five diseases using the Th1 (light blue) and Treg (dark blue) models showed higher fractions of nominally significant genes than that of normal differential gene expression tests. C: Measurement of actual protein levels of the predicted proteins in patients with early MS (clinically isolated syndrome (CIS)) vs healthy controls (HC) and pre vs post one-year treatment with Natalizumab. sCD27 was measured in cerebrospinal fluid (CSF) using ELISA. Left plots show healthy controls vs CIS where patients with no evidence of disease activity (NEDA) at four years are shown as filled circles. D: Receiver operating curve using sCD27 concentration as a single prognostic marker of NEDA at four (solid line) and two years (dashed line) after CIS. 


\section{Application of Model to RNA-seq allows for the discovery of Protein Biomarkers}

As proteins carry out the majority of biological processes, they are the causative agents by which disease states are formed and are therefore considered as ideal biomarkers (Zhao et al., 2019). However, global studies of the proteome are difficult to perform outside of in vitro settings due to the large material requirements (the proteomics presented, as part of this thesis, for example required 20 times as many cells as the RNA-seq) and clinical studies as a result often rely on studies of gene expression with RNA-seq. It is therefore of great relevance to be able to predict what proteins are produced from the RNA.

As such, the Th1 and Treg models were applied to publicly available RNA-seq data from five complex immune diseases and the resulting predicted differentially expressed proteins searched for potential biomarkers. This showed a consistent increase in the number of predicted differentially expressed proteins over the common approach (limma) (Figure 13B). The greatest improvement was seen for the Th1 model in asthma and MS, which prompted us to further investigate their results for the presence of biomarkers. As an ideal biomarker would be secretory and therefore be easily measurable, we searched the predicted differentially expressed proteins using our protein models for secretory proteins that had previously been associated with the disease. In MS we found three candidates, Annexin A1, sCD40L and sCD27, which we then proceeded to validate in an independent cohort of patients with MS. Out of the three proteins, only sCD27 was expressed in the data. sCD27 levels showed high separation between patients and controls and was also able to predict disease activity (Figure 13C and D). 


\section{Combining ATAC-seq and RNA-seq to study Th1 differentiation (Paper IV)}

Paper IV was performed against the backdrop of paper II and as such, its results surrounding P4 and its significance to MS will be discussed together with paper II in the next section. However, the combination of ATAC-seq and RNA-seq presented a unique opportunity to study if the effect of Th1 differentiation on gene expression was also reflected in the accessibility of the surrounding chromatin. Through plotting the read coverage (RPKM) of the ATAC-seq and RNA-seq at key T-cell activation loci (CD69, IL2 and IFNG) as well as TBX21 (T-bet), the master regulator of Th1, and GATA3, the master regulator of Th2, we observed a concurrent gain in ATAC-seq coverage in the promoter region and exon coverage in the RNA-seq for CD69, IL2, IFNG and $T B X 21$. This clearly showing accessibility to go hand in hand with expression. Noteworthy was that for GATA3 a concurrent loss was instead observed consistent with its downregulation during Th1 differentiation (Luckheeram et al., 2012, p. 4) (Figure 14A). Additionally, a pathway enrichment analysis of both the ATAC-seq and RNA-seq showed enrichment for T-cell activation and differentiation (Figure 14B). Furthermore, a clear enrichment of motifs for TFs vital to T-cell activation such as JUN, FOS and STAT1 was observed in the peaks from the ATAC-seq showing a clear contribution of these regions to T-cell activation (Figure 14C).

Following these promising initial results, we set out to tie the RNA-seq to the ATAC-seq through annotating each peak to a corresponding gene and study the effect of P4 on Th1 differentiation, which we did through Pearson correlation. See methods for the discussion surrounding this choice of method. 


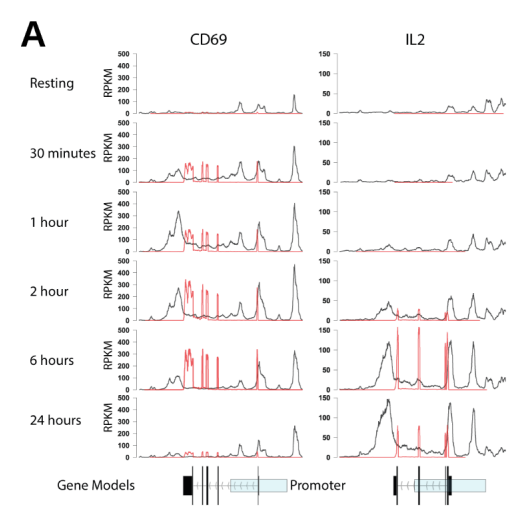

B
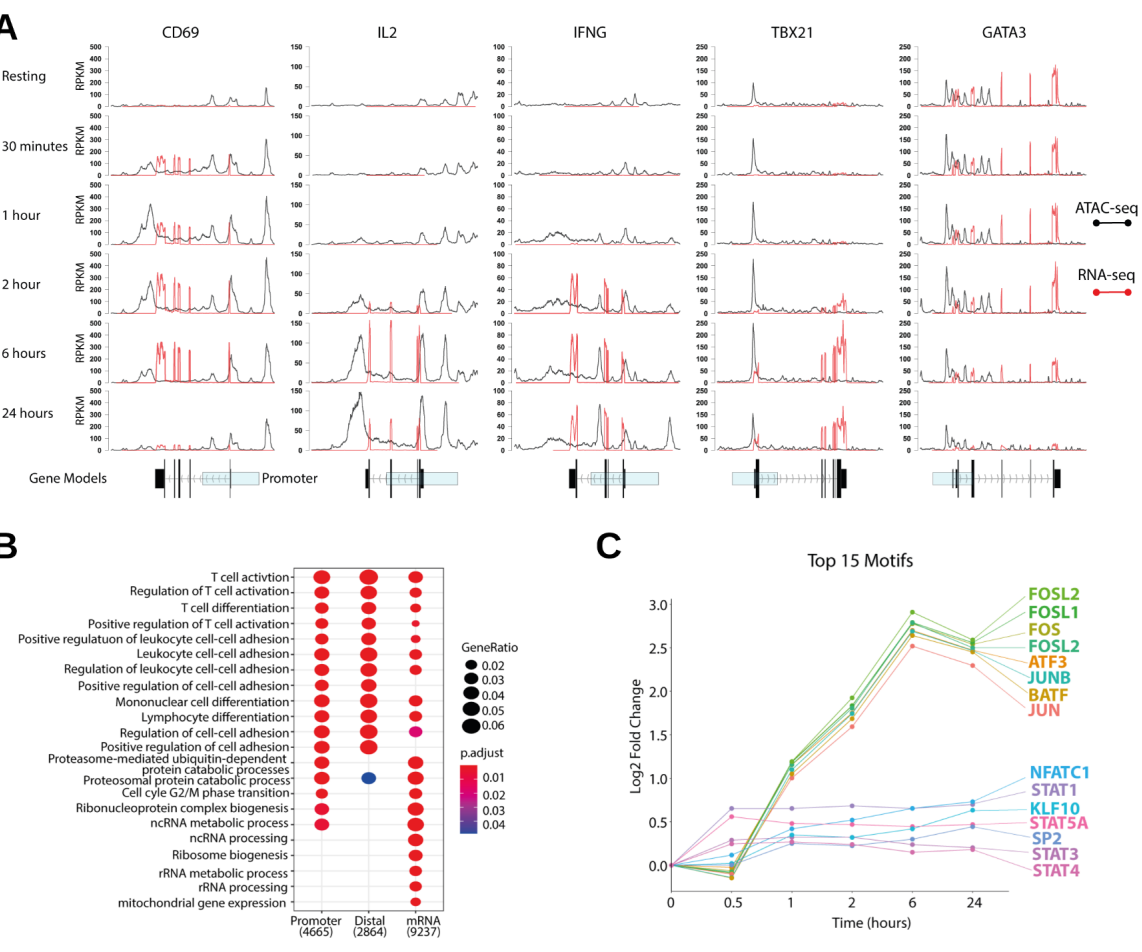

C

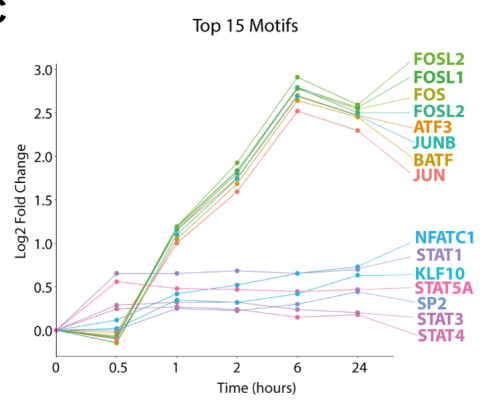

Figure 14: Changes in the chromatin and transcriptomic landscape during Th1 differentiation: A: Accessibility (black for ATAC-seq) and expression (red for RNA-seq) shown as RPKM for CD69, IL2, IFNG, TBX21 and GATA3 over time. Gene models of the genes with exons (black) and the promotor region (transparent blue) are displayed below. B: GO pathway enrichment of differentially accessible or expressed genes over the whole Th1 time series. C: Gain in percentage of total discovered motifs (compared to baseline) for the top 15 motifs presented as $\log 2$ fold change over the time series. $\mathrm{TF}=$ transcription factor, $\mathrm{Th} 1=\mathrm{T}$ helper 1 cells, $\mathrm{RPKM}=$ Reads per kilo base per million mapped reads.

\section{Multiple sclerosis as a disease and the significance of pregnancy (Paper II and IV)}

MS is

a chronic inflammatory disease of the central nervous system, characterised by the auto-inflammatory destruction of the myelin sheets, which acts as the insulation for the axonal circuits, by auto-reactive T- 
cells . MS manifests initially as a relapse-remitting disease with periods of increased and decreased inflammatory activity but eventually progresses into a progressive phase as damage to the central nervous system accumulates (Baecher-Allan et al., 2018) with accompanying decline in neurological function. During the relapse remitting stage of the disease, it has been observed that there is a marked reduction in relapses during pregnancy, to a similar rate as the effects achieved with most effective treatments in MS, with a marked increase post-partum (Confavreux et al., 1998; Polman et al., 2006). A similar effect has also been observed for the disease activity in other autoimmune disorders such as RA (Förger and Villiger, 2020) and psoriasis (Tauscher et al., 2002), clearly showing pregnancy to have a significant immunomodulatory effect. Pregnancy is an unusual situation for the immune system as it requires the establishment of a highly immunotolerant state as to avoid rejection of the foetus. This is thought to be mainly mediated by the major steroid hormones such as $\mathrm{P} 4$ which massively increase during pregnancy, followed by a marked decrease post-partum, essentially mirroring the relapse rate observed in MS (Arck et al., 2008). As such, we aimed to investigate the immunomodulatory effects of $\mathrm{P} 4$ on $\mathrm{CD} 4{ }^{+} \mathrm{T}$-cell activation (paper II) and Th1 differentiation (paper IV).

\section{The effects of progesterone on T-cell activation}

First, we set out to establish $\mathrm{P} 4$ to have a suppressive effect on $\mathrm{CD}^{+} \mathrm{T}$ cell activation by measuring the expression of the surface activation markers CD69 and CD25. In agreement with previous studies in the field (Ehring et al., 1998; Stites and Siiteri, 1983) CD4 ${ }^{+}$T-cells displayed lower levels of CD69 and CD25 cell surface expression following P4 treatment (Figure 15A-C) establishing P4s ability to inhibit T-cell activation. Then, to study the impact of $\mathrm{P} 4$ treatment on gene expression we performed RNA-seq on a time series of $\mathrm{CD}^{+} \mathrm{T}$ cells undergoing activation with P4 treatment at 6 and 24h. This showed P4 to induce large transcriptomic changes to the activating T-cells. Interestingly, in spite of P4 seemingly inducing a similar amount of 
upregulated and downregulated genes only the downregulated genes were enriched for immune related pathways when performing a gene set enrichment analysis of the significantly differentially expressed genes (Figure 15D and E). Additionally, these downregulated genes significantly overlapped with genes upregulated upon activation of $\mathrm{CD} 4^{+} \mathrm{T}$-cells further reinforcing a direct effect on activation (Figure 15F and G). This gene intersection will from here on be referred to as P4 response genes.

These results were further reinforced by the ATAC-seq and RNA-seq result in paper IV where P4 downregulated genes clearly overlapped with genes upregulated by the Th1 differentiation time series and these genes were enriched for major activation pathways when performing a pathway enrichment (Figure 16A and B). Additionally, the ATAC-seq peaks that were correlated to these genes were primarily enriched for motifs of major T-cell activation markers such as JUN, FOS, BATF, $A T F 3$ and NFATC1 (Figure 16C and D) further empathising $\mathrm{P} 4$ effect on $\mathrm{T}$-cell activation. 
A

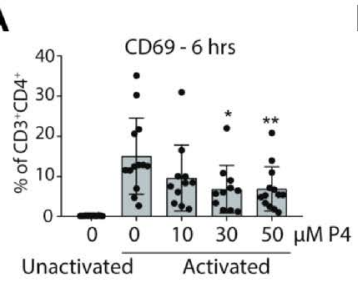

B

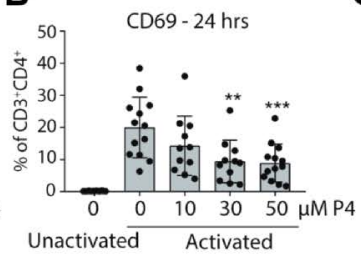

C

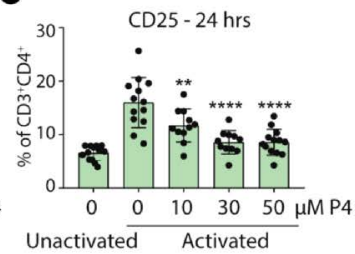

D

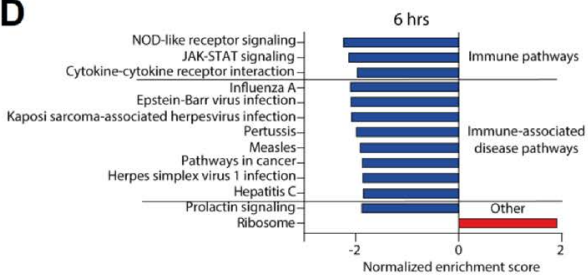

E

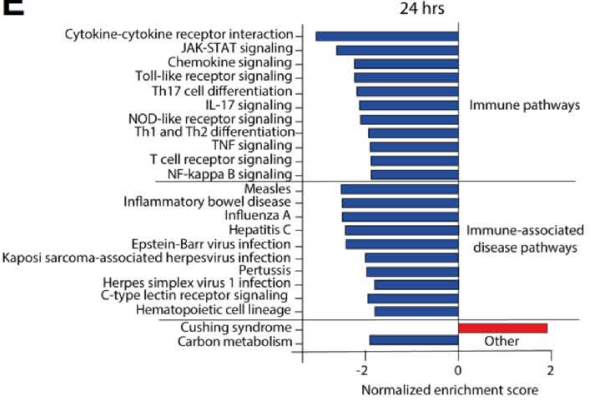

$\mathbf{F}$

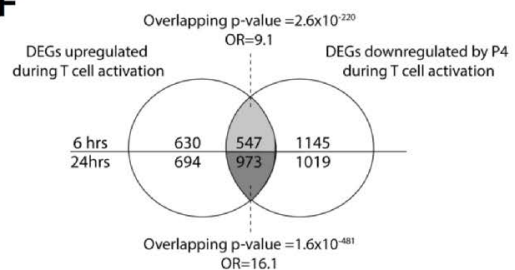

G

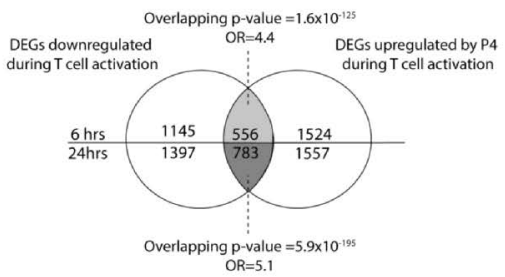

Figure 15: Progesterone dampens T-cell activation and induces transcriptomic changes in activated $\mathrm{CD4}^{+} \mathrm{T}$-cells downregulating immune-related pathways: A-C: The effect of $\mathrm{P} 4$ on T-cell activation markers CD69 (6 and $24 \mathrm{hrs)} \mathrm{and} \mathrm{CD25} \mathrm{(24} \mathrm{hrs} \mathrm{only)} \mathrm{was} \mathrm{analyzed} \mathrm{by} \mathrm{flow}$ cytometry ( $\mathrm{n}=11-13)$. Bar graphs show the percentages of $\mathrm{CD} 4^{+} \mathrm{T}$-cells expressing the T-cell activation markers. Mean \pm standard deviation is shown. ${ }^{*} \mathrm{p} \leq 0.05, * * \mathrm{p} \leq 0.01, * * * \mathrm{p} \leq 0.001, * * * * \mathrm{p} \leq 0.0001$. D and $\mathbf{E}$ : Bar graphs showing the normalized enrichments score on the $\mathrm{x}$-axis from the KEGG gene set enrichment analysis of the $\mathrm{P} 4$ response genes (DEGs comparing activation in the presence of $\mathrm{P} 4$ as compared to activation alone) at 6 and $24 \mathrm{hrs}$. All pathways have an FDR adjusted $p$-value $<0.05$. F and G: Venn diagrams of the overlapping DEGs between up-and down-regulated genes in T-cells activated in the presence or absence of $50 \mu \mathrm{M} \mathrm{P} 4 . \mathrm{n}=3$ unactivated, $\mathrm{n}=8$ activated with and without $50 \mu \mathrm{M}$ P4. DEGs, differentially expressed genes: $\mathrm{OR}$, odds ratio; $\mathrm{P} 4$, progesterone. 
A

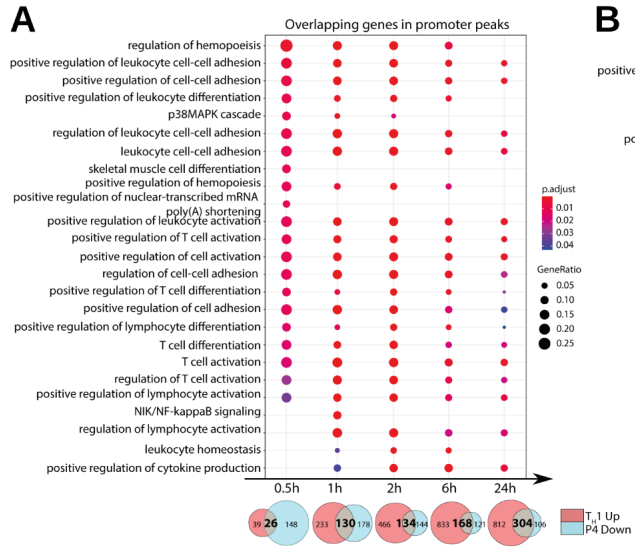

C

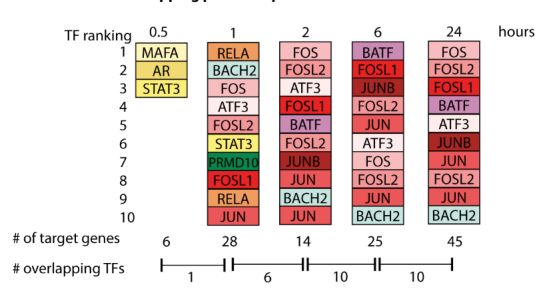

B

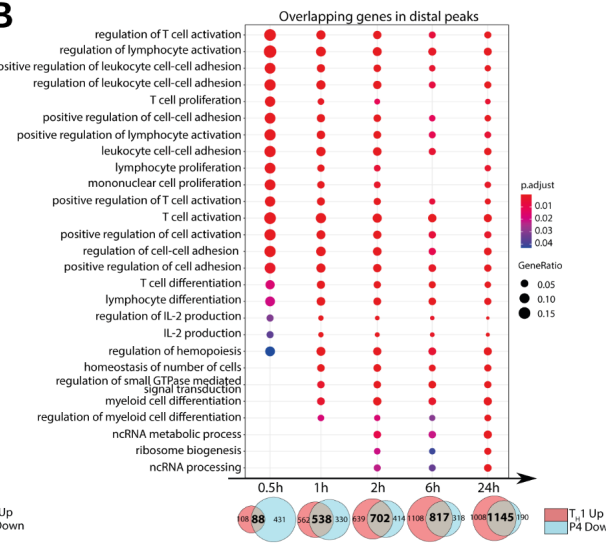

D

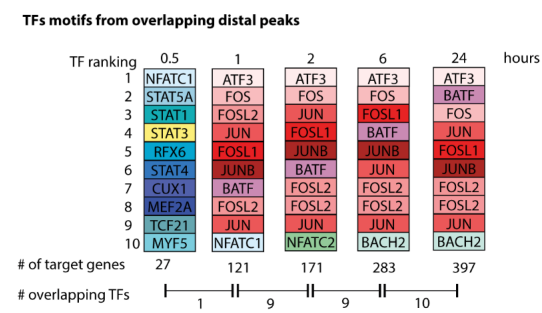

Figure 16: Progesterone downregulates T-cell responses induced during Th1 differentiation: A and B: Gene Ontology pathway enrichment analysis of the overlapping genes between peaks that were upregulated during Th1 differentiation and downregulated by $\mathrm{P} 4$. Venn diagrams shown below highlight the overlapping genes between the genes upregulated in Th1 and downregulated with P4, where the intersection was used for the gene set enrichment. C and D: Top 10 transcription factors derived from motif enrichment analysis of the intersecting peaks between Th1 up and P4 down at each time point. The TFs are colored in the same color among the same TF and between promoter and distal. A TF can appear more than ones for each time point since different motifs from the same TF are present. Number of target genes regulated by these TFs and the number of shared TFs between the time points are given below. All TFs are significantly enriched compared to time point 0 (resting; $\mathrm{p}<0.05$ ) at each respective timepoint they appear. 


\section{Progesterone downregulated genes and peaks are enriched for disease genes and SNPs}

As P4 levels during pregnancy, as previously stated, seem to follow the reduction in disease relapse rate, we aimed to investigate if the P4 response genes were previously known disease genes. This, in paper II, showed a clear enrichment of all studied autoimmune diseases such as RA and MS clearly implying P4 to have a significant effect on genes central to autoimmune diseases (Figure 17A). Similarly, in paper IV we analysed the peaks tied to the P4 response genes for enrichment of SNP associated peaks. This again showed enrichment for MS and RA further reinforcing $\mathrm{P} 4 \mathrm{~s}$ central role in autoimmunity (Figure 17B and C). Further analysis of these disease associated genes from paper II for downstream targets of transcription factors showed an enrichment for targets of STAT1 and STAT3 (Figure 17D and E). STAT1 and STAT3 were also among the earliest TFs observed as enriched in the peaks of the P4 response genes in paper IV clearly implicating them as central targets of the $\mathrm{P} 4$ disease associated effect on $\mathrm{T}$-cell activation (Figure $16 \mathrm{C}$ and $\mathrm{D})$. 

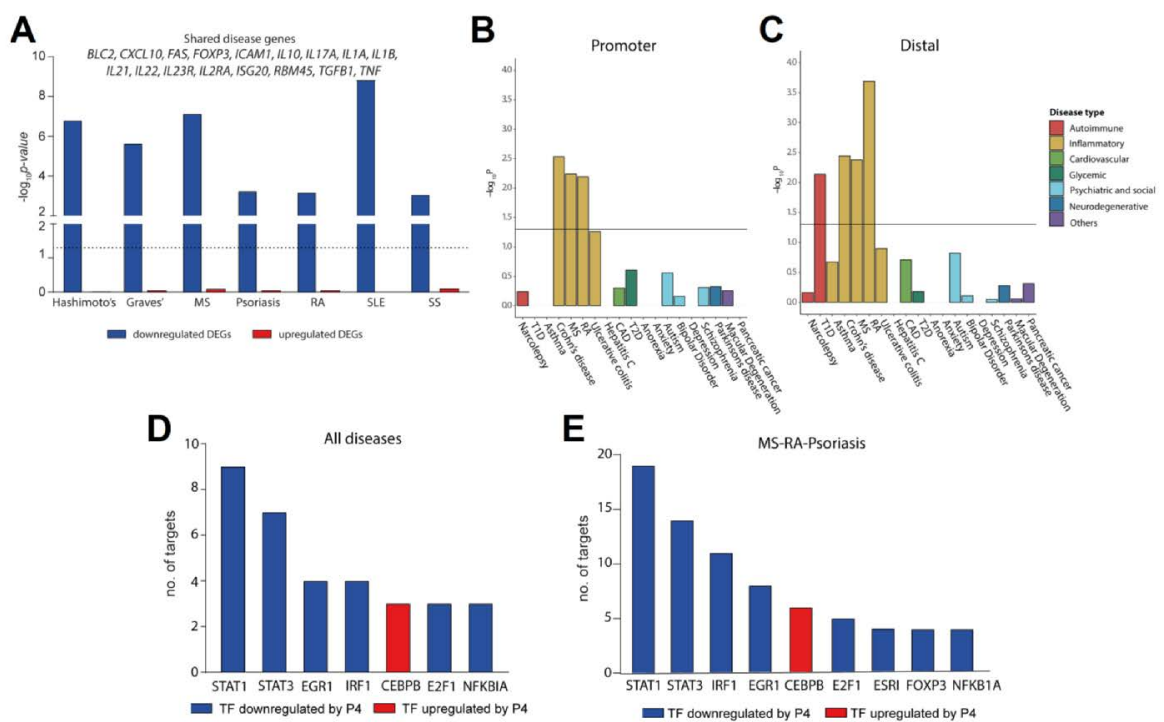

Figure 17: Progesterone downregulates disease-associated genes and peaks for several autoimmune diseases: A (paper II): Enrichment of disease-associated genes for seven autoimmune diseases among the differentially expressed genes (DEG) by P4. Downregulated DEGs $=$ blue bars, upregulated DEGs = red bars. The genes that are common between all seven diseases among the differentially downregulated genes by $\mathrm{P} 4$ are depicted above the bars. B and C (paper IV): Enrichment of disease-SNPassociated peaks among the overlapping promoter $(\mathbf{B})$ and distal peaks $(\mathbf{C})$ for nineteen diseases. Line shows $p=0.05$. Enrichment $p$ values were calculated by Fisher's exact test. D and E (paper II): The TFs with the highest number of interacting genes among the disease-associated differentially downregulated genes for (D) shared genes between the seven different diseases (from A) (out of 36 TFs in total) and (E) common genes between MS, RA and psoriasis (out of 57 TFs in total).

\section{Analysis of RA and MS associated peaks implicates JUN} as a central regulator of $P 4$ response genes

In paper IV, as RA and MS are traditionally considered as Th1 associated we performed an in depth analysis of the TF peak interactions among peaks associated with MS and RA. This clearly showed most interactions to be distal (Figure 18A) as is consistent with most GWAS SNPs being present in non-coding regions (Edwards et al., 2013). A target common between MS and RA was IL2RA, a major 
player in Th1 differentiation as signalling by IL-2 through IL2RA is vital to growth and clonal expansions during differentiation (Malek, 2008). It should be noted however that IL-2 signalling is not only vital to Th1 as it carries a similar role in Th2 and Th17 differentiation as well and maintaining IL-2 signalling long term is vital to Treg differentiation (Malek, 2008). Blocking of IL-2 singling by P4 however would indeed inhibit T-cell activation contributing to its observed general dampening of immune responses. Shared TFs implicated by this analysis included $J U N$ a member of the AP-1 complex (Shaulian and Karin, 2002).

Additionally, several of the other members of the AP-1 complex such as $A T F 3, F O S$ and BATF3 were similarity implicated for either RA or MS and were among the major regulators of the $\mathrm{P} 4$ response genes, emphasizing the central importance of AP-1. AP-1 signalling through $M A P K, J N K$ and $E R K$ in T-cells is vital to maintain growth and survival and drives the expression of IL-2 (Figure 4) again implying an inhibitory effect of P4 on IL-2. Furthermore, AP-1 activity has been implicated as the major TF responsible for the chromatin remodelling that takes place during T-cell activation and sites of AP-1 activity overlap strongly with risk loci for immunological diseases, especially MS (Yukawa et al., 2020).

As $J U N$ was both implicated as a shared disease TF and was a central regulator of the $\mathrm{P} 4$ response genes we sought to further investigate its relevance to MS by investigating publicly available ChIP-seq data for $J U N$. This again showed MS associated SNPs to be highly enriched among both promoter and distal binding elements of JUN (Figure 18B). Finally, these SNPs were highly enriched as expression quantative trait loci (eQTLs) (Figure 18C) implicating them as capable of influencing gene expression. 


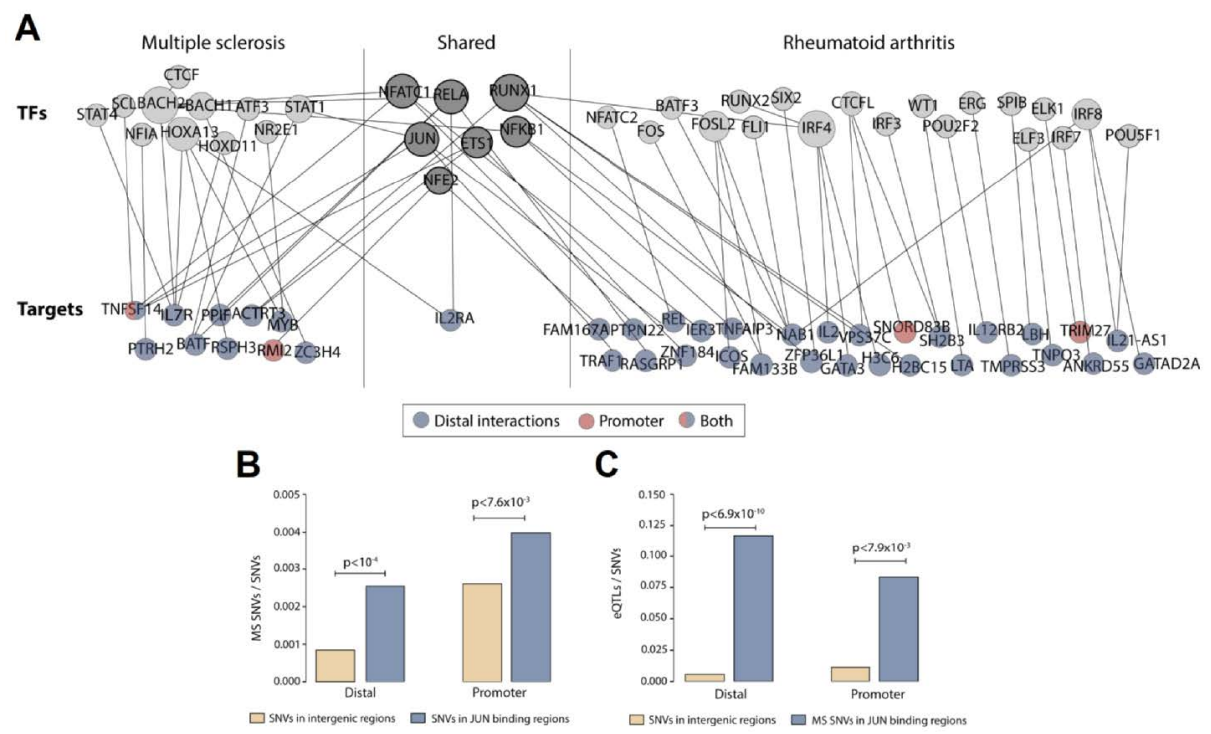

Figure 18: Network analysis implicates $J U N$ as a central regulator of $P 4$ disease associated responses: A: Network of the genes and TFs present in the overlapping promoter and distal peaks for MS and RA. Shared TFs and genes are present in both diseases. The target genes have been colored based on if the gene is associated to the promoter peaks (red), distal peaks (blue) or both (blue and red). Some of the genes were denoted both as TFs and targets. (F) Proportion of MS-associated SNPs among common SNVs in intergenic regions compared to JUN binding sites, both for the distal and promoter regions. Statistical differences were determined using permutation test $(10,000$ permutations). (G) Proportion of eQTLs among SNVs in intergenic regions compared to proportion of eQTLs among MS-associated SNPs in JUN binding sites, both for the distal and promoter regions. Fisher's exact test was used to determine statistical differences.

\section{Long-term effects of P4 and influence on STATs}

In paper II, STAT1 and STAT3 were implicated as major upstream regulators of P4 response genes (Figure 17D and E). Similarly, in paper IV we observed STAT1, STAT3, STAT4 and STAT5A as early regulators of P4 response genes (Figure 16C and D) and as early regulators of Th1 as a whole (Figure 15C). Additionally, STAT1 and STAT4 were observed as regulators of MS associated peaks (Figure 18A). Taken together this implies a direct effect on Th1 and that this is connect to MS. However, the long-term impact of P4s effect on STATs 
Olof Rundquist

would require further investigation as Th1 differentiation spans over the course of several days and we only studied the first $24 \mathrm{~h}$. Still, long-term effects have been observed on cytokine production in culture with P4 implying P4 to have long-term effects on T-cell differentiation (AbdulHussain et al., 2020; Miyaura and Iwata, 2002; Piccinni et al., 1995). 


\section{Conclusions and Future perspectives}

Throughout this thesis, by relying on multiple types of data we could corroborate results between different levels of regulation and make novel insights into the differentiation of Th1 and the effects of $\mathrm{P} 4$ on this process. In paper IV, the use of ATAC-seq allowed for the interrogation of TF binding events and through correlation, we could tie these to effects on the expression of disease relevant genes. Similarly, in paper III, through combining RNA-seq and proteomics we could provide insight on the influence of multiple splice variants on the correlation of mRNA to its respective protein and use this information for biomarker discovery. It is however important to consider the biases in this type of data driven analysis. While ATAC-seq allows for the prediction of potentially bound sites in the genome through footprinting and to use this data to look at TF gene interactions it is important to remember that these are just predictions. TF footprints are rarely experimentally validated on a global scale, as the gold standard for validation is CHiP-seq, which is usually performed on only a small set of TFs per experiment. Additionally, in our case we used the homer database of motifs to match our footprints to TFs, this is a database made primarily of motifs validated through CHiP-seq. As such, it is limited to only the subset of TFs that have reliable antibodies for CHiPseq analysis. Due to the material needs and cost of CHiP-seq along with the fact that immunology is a hot topic in science, there is additionally a bias in what TFs are being studied and therefore make it into the database resulting in a bias towards immune specific TFs. Furthermore, most CHiP-seq assay are performed in model systems such as cell lines where co-associating factors present may not be the same as in a primary cell system which may influence TF binding. As such, it is therefore important that the assays used to validate TF-gene interactions are expanded and applied to a greater variety of systems to limit the knowledge bias currently inherent to TF-gene interactions. These biases are why we in paper IV sought to the greatest extent possible to corroborate results between ATAC-seq accessibility, TF-gene 


\section{Olof Rundquist}

interactions (both promoter and distal), and mRNA expression to make robust conclusions about the effects of $\mathrm{P} 4$ on Th1 differentiation. These biases may however in part explain why such a small set of TFs were continually identified to govern both Th1 and P4 responses in Paper IV.

Additionally, it is unclear how $\mathrm{P} 4$ excretes its effects on $\mathrm{CD} 4^{+} \mathrm{T}$-cells as there is limited evidence for the expression of the nuclear progesterone receptor (PGR) in $\mathrm{CD}^{+}{ }^{+} \mathrm{T}$-cells. Indeed, we did not detect $P G R$ expression in any of our presented $\mathrm{CD}^{+}{ }^{+} \mathrm{T}$-cell RNA-seq datasets and there was no ATAC-seq peak around the gene implying it to be inactive. P4 however does have several membrane-bound receptors, some of which were expressed, which it may bind to. The knowledge of what effects these receptors have on $\mathrm{CD}^{+}{ }^{+} \mathrm{T}$-cells is however limited and additional studies with synthetic prostaglandins specific for these receptors would be required to make further conclusions. P4 may additionally, as it is a steroid hormone, bind to other steroid hormone receptors, most significantly the glucocorticoid receptors, that are known to have significant immunosuppressive effects (see discussion, paper II). While the mechanism of $\mathrm{P} 4$ effects on $\mathrm{CD}^{+} \mathrm{T}$-cells remains obscured it is from our results clear that it has significant immunosuppressive effects by centrally inhibiting T-cell activation, possibly through inhibiting IL-2 signaling, and as such should be trialed as a treatment.

Paper III relied on the integration of splice variant information to predict protein abundance. These predictions were based on the splice variants currently available in the ENSEMBL database and as such contains a mix of experimentally validated and computationally generated splice variants. This involved the calculation of weights for each splice variant to determine to what extent the expression of each splice variants contribute to the detected protein in the proteomics. These weights are difficult to validate as protein isoform (splice variant) quantification is excessively difficult due the limited amount of peptides identified from any one protein. Additionally, there was a lack of correlation between these weights between different cell-types such as 
the model constructed for Treg. Therefore, the model constructed in paper III could have benefited from the integration of further data on how splice variants contribute to the abundance of a protein such as the data presented in APPRIS (Rodriguez et al., 2013).

In paper I, we established TET2 a key target for silencing in the development of pediatric T-ALL showing the importance of epigenetic factors in cancer transformation. Frequent miss-expression of TET2 has previously been reported in Adult T-cell leukemia/lymphoma (Marçais et al., 2017). Pediatric cancers feature an overall lower mutational burden as compared to adult cancers (Filbin and Monje, 2019; Gröbner et al., 2018; Ma et al., 2018) but must none the less pass through the same barriers to transformation. It is therefore tempting to speculate that pediatric cancers may make up for their lack of mutations by instead silencing tumor suppressors such as TET2 rather than mutating them.

In summary, this thesis provides an important foundation for future work the development and differentiation of T-cells. Multiple methods were applied to corroborate results between different types of data as to make robust conclusions. This allowed for the discovery of upstream disease regulators, biomarkers, and possible treatments. In paper I, we studied the TET2 gene and investigated its importance in T-ALL for treatment susceptibility and mechanism in vitro. Through the analysis of data on gene methylation and expression, we showed TET2 to be frequently repressed and/or silenced in T-ALL implicating it as major target during T-ALL transformation. Additionally, through treatment with decitabine, an inhibitor of DNA-methylation, and Vitamin C, a cofactor for TET2, we showed that TET2 deficient cancer cell lines were more vulnerable to treatment targeting DNA methylation and investigated the mechanistic effects of said treatment by RNA sequencing. This showed that decitabine treatment induced the expression of previously silenced genes, among them TET2, as well as retrotransposons implying decitabine as viable treatment option in TALL. In paper II, we studied T-cell activation and its importance to MS 


\section{Olof Rundquist}

to understand the role of T-cells in mediating the lowered disease activity usually observed during pregnancy in MS. This showed that the major pregnancy hormone progesterone (P4) significantly dampened Tcell activation, providing a possible explanation for the beneficial effects of pregnancy on MS. Additionally, these effects were shown to be mainly mediated by targets of STAT1 and STAT3 showing them to be central to the effects induced by P4. In paper III and IV, using ATACseq, RNA-seq and proteomics we studied Th1-differentiation as a time series to elucidate regulatory events throughout the differentiation process and to study their implications for MS with the inclusion of P4 treatment in paper IV. In paper III, we focused on the integration of RNA-seq and proteomics by designing a model for the prediction of protein abundance from RNA-seq. This showed the inclusion of spice variant information as well as time delay to allow for the accurate predication of protein abundance from mRNA expression. Additionally, through applying this modelling approach to dataset of mRNA expression from immune related diseases we were able to predict possible biomarkers, one of which we proceeded to validate in MS. In paper IV, we focused on the integration of ATAC-seq and RNA-seq using correlation between time series of the two techniques and implemented P4 treatment to study its effect on Th1 differentiation. This further reinforced the results of paper II once again emphasising P4's effects to be mainly mediated through its effects on T-cell activation where it significantly affected several aspects of $I L-2$ signalling. Furthermore, $J U N$, a member of the AP-1 complex, was implicated as a major regulator of the effects observed on MS and RA associated chromatin. 


\section{$\underline{\text { Acknowledgements }}$}

It has been a good few years and I wish to thank everyone that I have met over the years of the PhD. You made this the best years I have had.

To Mika Gustafsson my main supervisor and mentor in bioinformatics, thank you for all of the support over the years and for introducing me to and teaching me bioinformatics.

To Colm Nestor my co-supervisor and original mentor as a master and post graduate student, thank you for taking me in, for your always on point critique, unwavering support and inspiring me to always do better.

To the collaborators, to Maria Jenmalm, Jan Ernerudh and Claudio Altafini for your help with articles and valuable feedback through the SSF collaboration over the years and to Min-Sik Kim for your help with the proteomics and the welcome in the republic of Korea.

To all members of the research groups at the technical and medical faculty, past and present, thank you for always providing a fun and friendly atmosphere for "scientific" discussion and invaluable support over the years. Special thanks to Maike Bensberg for all of the help in the lab and with articles, many a fun nights and inspiring dedication. To Antonio Lentini for introducing me to the group and for all of your help over the first years of the PhD. To Tejaswe Badam for being a great friend over the years, the grand welcome to India and many a fun nights. To David Martinez for finally getting me into the gym and for all of the help with R. Finally, to Sandra Hellberg, Björn Gylemo, Cathrine Lagerwall, Georgia Papapavlou, Johanna Raffetseder, Aida Selimovic, Andreas Tjärnberg, Rasmus Magnusson, Julia Åkesson and Alberto Zenere for many a fun conversations and help with articles. 
To all colleagues at cell biology floor 13, past and present. To Björn Ingelsson for all of the help with proteins, for always having exactly the reagent one needs and many a fun stories. To Annelie Lindstöm for your support as $\mathrm{PhD}$ coordinator at the medical faculty and at admission seminars. Finally, to Mikael Benson, Danuta Gawel, Huan Zhang and Sandra Lilja as well as everyone else who made cell biology floor 13 such a fun place when I was there.

To all other colleagues and friends throughout the university, to the lads, Mike Jury, Tejaswe Badam, Konah and Pelle for many fun social events and support. To everyone else, Lovisa Örkenby, Arnaud le Febvrier, Tim Cornelissen, Elin Lindstöm and everyone else I have met over the years. You have made this the best years I have had.

To the PhD Union at the Medical Faculty, DOMFIL, for the support and many a fun events over the years.

Finally to the family for always being there and making sure I take care of myself. 


\section{$\underline{\text { References }}$}

AbdulHussain, G., Azizieh, F., Makhseed, M., Raghupathy, R., 2020. Effects of Progesterone, Dydrogesterone and Estrogen on the Production of Th1/Th2/Th17 Cytokines by Lymphocytes from Women with Recurrent Spontaneous Miscarriage. J. Reprod. Immunol. 140, 103132. https://doi.org/10.1016/j.jri.2020.103132

Adams, A.B., Ford, M.L., Larsen, C.P., 2016. Costimulation Blockade in Autoimmunity and Transplantation: The CD28 Pathway. J. Immunol. Baltim. Md 1950 197, 2045-2050. https://doi.org/10.4049/jimmunol.1601135

Adey, A., Morrison, H.G., Asan, null, Xun, X., Kitzman, J.O., Turner, E.H., Stackhouse, B., MacKenzie, A.P., Caruccio, N.C., Zhang, X., Shendure, J., 2010. Rapid, low-input, low-bias construction of shotgun fragment libraries by high-density in vitro transposition. Genome Biol. 11, R119. https://doi.org/10.1186/gb-2010-11-12-r119

Agathocleous, M., Meacham, C.E., Burgess, R.J., Piskounova, E., Zhao, Z., Crane, G.M., Cowin, B.L., Bruner, E., Murphy, M.M., Chen, W., Spangrude, G.J., Hu, Z., DeBerardinis, R.J., Morrison, S.J., 2017. Ascorbate regulates haematopoietic stem cell function and leukaemogenesis. Nature 549, 476-481. https://doi.org/10.1038/nature23876

Amur, S., Parekh, A., Mummaneni, P., 2012. Sex differences and genomics in autoimmune diseases. J. Autoimmun. 38, J254265. https://doi.org/10.1016/j.jaut.2011.12.001

Arck, P.C., Rücke, M., Rose, M., Szekeres-Bartho, J., Douglas, A.J., Pritsch, M., Blois, S.M., Pincus, M.K., Bärenstrauch, N., Dudenhausen, J.W., Nakamura, K., Sheps, S., Klapp, B.F., 2008. Early risk factors for miscarriage: a prospective cohort study in pregnant women. Reprod. Biomed. Online 17, 101-113. https://doi.org/10.1016/s1472-6483(10)60300-8

Baecher-Allan, C., Kaskow, B.J., Weiner, H.L., 2018. Multiple Sclerosis: Mechanisms and Immunotherapy. Neuron 97, 742-768. https://doi.org/10.1016/j.neuron.2018.01.021

Baylin, S.B., Jones, P.A., 2011. A decade of exploring the cancer epigenome - biological and translational implications. Nat. Rev. Cancer 11, 726-734. https://doi.org/10.1038/nrc3130 
Belver, L., Ferrando, A., 2016. The genetics and mechanisms of T cell acute lymphoblastic leukaemia. Nat. Rev. Cancer 16, 494-507. https://doi.org/10.1038/nrc.2016.63

Bentsen, M., Goymann, P., Schultheis, H., Klee, K., Petrova, A., Wiegandt, R., Fust, A., Preussner, J., Kuenne, C., Braun, T., Kim, J., Looso, M., 2020. ATAC-seq footprinting unravels kinetics of transcription factor binding during zygotic genome activation. Nat. Commun. 11, 4267. https://doi.org/10.1038/s41467-020-18035-1

Blom, B., Spits, H., 2006. Development of human lymphoid cells. Annu. Rev. Immunol. 24, 287-320. https://doi.org/10.1146/annurev.immunol.24.021605.090612

Bray, N.L., Pimentel, H., Melsted, P., Pachter, L., 2016. Near-optimal probabilistic RNA-seq quantification. Nat. Biotechnol. 34, 525527. https://doi.org/10.1038/nbt.3519

Buenrostro, J.D., Giresi, P.G., Zaba, L.C., Chang, H.Y., Greenleaf, W.J., 2013. Transposition of native chromatin for fast and sensitive epigenomic profiling of open chromatin, DNA-binding proteins and nucleosome position. Nat. Methods 10, 1213-1218. https://doi.org/10.1038/nmeth.2688

Cameron, E., Pauling, L., 1978. Supplemental ascorbate in the supportive treatment of cancer: reevaluation of prolongation of survival times in terminal human cancer. Proc. Natl. Acad. Sci. U. S. A. 75, 4538-4542. https://doi.org/10.1073/pnas.75.9.4538

Cao, Y., Goods, B.A., Raddassi, K., Nepom, G.T., Kwok, W.W., Love, J.C., Hafler, D.A., 2015. Functional inflammatory profiles distinguish myelin-reactive $\mathrm{T}$ cells from patients with multiple sclerosis. Sci. Transl. Med. 7, 287 ra74. https://doi.org/10.1126/scitranslmed.aaa8038

Chemin, K., Gerstner, C., Malmström, V., 2019. Effector Functions of CD4+ T Cells at the Site of Local Autoimmune InflammationLessons From Rheumatoid Arthritis. Front. Immunol. 10, 353. https://doi.org/10.3389/fimmu.2019.00353

Chen, C.-H., Zheng, R., Tokheim, C., Dong, X., Fan, J., Wan, C., Tang, Q., Brown, M., Liu, J.S., Meyer, C.A., Liu, X.S., 2020.

Determinants of transcription factor regulatory range. Nat. Commun. 11, 2472. https://doi.org/10.1038/s41467-020-16106$\mathrm{X}$

Chen, Q., Espey, M.G., Krishna, M.C., Mitchell, J.B., Corpe, C.P., Buettner, G.R., Shacter, E., Levine, M., 2005. Pharmacologic ascorbic acid concentrations selectively kill cancer cells: action as a pro-drug to deliver hydrogen peroxide to tissues. Proc. Natl. 
Acad. Sci. U. S. A. 102, 13604-13609.

https://doi.org/10.1073/pnas.0506390102

Cheng, M., Anderson, M.S., 2018. Thymic tolerance as a key brake on autoimmunity. Nat. Immunol. 19, 659-664. https://doi.org/10.1038/s41590-018-0128-9

Christman, J.K., 2002. 5-Azacytidine and 5-aza-2'-deoxycytidine as inhibitors of DNA methylation: mechanistic studies and their implications for cancer therapy. Oncogene 21, 5483-5495. https://doi.org/10.1038/sj.onc.1205699

Cimmino, L., Dolgalev, I., Wang, Y., Yoshimi, A., Martin, G.H., Wang, J., Ng, V., Xia, B., Witkowski, M.T., Mitchell-Flack, M., Grillo, I., Bakogianni, S., Ndiaye-Lobry, D., Martín, M.T., Guillamot, M., Banh, R.S., Xu, M., Figueroa, M.E., Dickins, R.A., Abdel-Wahab, O., Park, C.Y., Tsirigos, A., Neel, B.G., Aifantis, I., 2017.

Restoration of TET2 Function Blocks Aberrant Self-Renewal and Leukemia Progression. Cell 170, 1079-1095.e20. https://doi.org/10.1016/j.cell.2017.07.032

Confavreux, C., Hutchinson, M., Hours, M.M., Cortinovis-Tourniaire, P., Moreau, T., 1998. Rate of pregnancy-related relapse in multiple sclerosis. Pregnancy in Multiple Sclerosis Group. N. Engl. J. Med. 339, 285-291. https://doi.org/10.1056/NEJM199807303390501

Corces, M.R., Buenrostro, J.D., Wu, B., Greenside, P.G., Chan, S.M., Koenig, J.L., Snyder, M.P., Pritchard, J.K., Kundaje, A., Greenleaf, W.J., Majeti, R., Chang, H.Y., 2016. Lineage-specific and single-cell chromatin accessibility charts human hematopoiesis and leukemia evolution. Nat. Genet. 48, 11931203. https://doi.org/10.1038/ng.3646

Corces, M.R., Trevino, A.E., Hamilton, E.G., Greenside, P.G., SinnottArmstrong, N.A., Vesuna, S., Satpathy, A.T., Rubin, A.J., Montine, K.S., Wu, B., Kathiria, A., Cho, S.W., Mumbach, M.R., Carter, A.C., Kasowski, M., Orloff, L.A., Risca, V.I., Kundaje, A., Khavari, P.A., Montine, T.J., Greenleaf, W.J., Chang, H.Y., 2017. An improved ATAC-seq protocol reduces background and enables interrogation of frozen tissues. Nat. Methods 14, 959962. https://doi.org/10.1038/nmeth.4396

Coustan-Smith, E., Mullighan, C.G., Onciu, M., Behm, F.G., Raimondi, S.C., Pei, D., Cheng, C., Su, X., Rubnitz, J.E., Basso, G., Biondi, A., Pui, C.-H., Downing, J.R., Campana, D., 2009. Early T-cell precursor leukaemia: a subtype of very high-risk acute lymphoblastic leukaemia. Lancet Oncol. 10, 147-156. https://doi.org/10.1016/S1470-2045(08)70314-o 
Creagan, E.T., Moertel, C.G., O'Fallon, J.R., Schutt, A.J., O'Connell, M.J., Rubin, J., Frytak, S., 1979. Failure of high-dose vitamin C (ascorbic acid) therapy to benefit patients with advanced cancer. A controlled trial. N. Engl. J. Med. 301, 687-690. https://doi.org/10.1056/NEJM197909273011303

Dobin, A., Davis, C.A., Schlesinger, F., Drenkow, J., Zaleski, C., Jha, S., Batut, P., Chaisson, M., Gingeras, T.R., 2013. STAR: ultrafast universal RNA-seq aligner. Bioinformatics 29, 15-21. https://doi.org/10.1093/bioinformatics/bts635

Edwards, S.L., Beesley, J., French, J.D., Dunning, A.M., 2013. Beyond GWASs: illuminating the dark road from association to function. Am. J. Hum. Genet. 93, 779-797. https://doi.org/10.1016/j.ajhg.2013.10.012

Egerton, M., Scollay, R., Shortman, K., 1990. Kinetics of mature T-cell development in the thymus. Proc. Natl. Acad. Sci. U. S. A. 87, 2579-2582. https://doi.org/10.1073/pnas.87.7.2579

Ehring, G.R., Kerschbaum, H.H., Eder, C., Neben, A.L., Fanger, C.M., Khoury, R.M., Negulescu, P.A., Cahalan, M.D., 1998. A nongenomic mechanism for progesterone-mediated immunosuppression: inhibition of $\mathrm{K}+$ channels, Ca2+ signaling, and gene expression in T lymphocytes. J. Exp. Med. 188, 15931602. https://doi.org/10.1084/jem.188.9.1593

Esensten, J.H., Helou, Y.A., Chopra, G., Weiss, A., Bluestone, J.A., 2016. CD28 Costimulation: From Mechanism to Therapy. Immunity 44, 973-988. https://doi.org/10.1016/j.immuni.2016.04.020

Ferrero, S., Esposito, F., Biamonti, M., Bentivoglio, G., Ragni, N., 2008. Myasthenia gravis during pregnancy. Expert Rev. Neurother. 8, 979-988. https://doi.org/10.1586/14737175.8.6.979

Filbin, M., Monje, M., 2019. Developmental origins and emerging therapeutic opportunities for childhood cancer. Nat. Med. 25, 367-376. https://doi.org/10.1038/s41591-019-0383-9

Förger, F., Villiger, P.M., 2020. Immunological adaptations in pregnancy that modulate rheumatoid arthritis disease activity. Nat. Rev. Rheumatol. 16, 113-122. https://doi.org/10.1038/s41584-019-0351-2

Fortelny, N., Overall, C.M., Pavlidis, P., Freue, G.V.C., 2017. Can we predict protein from mRNA levels? Nature 547, E19-E20. https://doi.org/10.1038/nature22293

Galas, D.J., Schmitz, A., 1978. DNAse footprinting: a simple method for the detection of protein-DNA binding specificity. Nucleic Acids Res. 5, 3157-3170. https://doi.org/10.1093/nar/5.9.3157 
Goryshin, I.Y., Reznikoff, W.S., 1998. Tn5 in vitro transposition. J. Biol. Chem. 273, 7367-7374.

https://doi.org/10.1074/jbc.273.13.7367

Gröbner, S.N., Worst, B.C., Weischenfeldt, J., Buchhalter, I.,

Kleinheinz, K., Rudneva, V.A., Johann, P.D., Balasubramanian, G.P., Segura-Wang, M., Brabetz, S., Bender, S., Hutter, B., Sturm, D., Pfaff, E., Hübschmann, D., Zipprich, G., Heinold, M., Eils, J., Lawerenz, C., Erkek, S., Lambo, S., Waszak, S., Blattmann, C., Borkhardt, A., Kuhlen, M., Eggert, A., Fulda, S., Gessler, M., Wegert, J., Kappler, R., Baumhoer, D., Burdach, S., Kirschner-Schwabe, R., Kontny, U., Kulozik, A.E., Lohmann, D., Hettmer, S., Eckert, C., Bielack, S., Nathrath, M., Niemeyer, C., Richter, G.H., Schulte, J., Siebert, R., Westermann, F., Molenaar, J.J., Vassal, G., Witt, H., ICGC PedBrain-Seq Project, ICGC MMML-Seq Project, Burkhardt, B., Kratz, C.P., Witt, O., van Tilburg, C.M., Kramm, C.M., Fleischhack, G., Dirksen, U., Rutkowski, S., Frühwald, M., von Hoff, K., Wolf, S., Klingebiel, T., Koscielniak, E., Landgraf, P., Koster, J., Resnick, A.C., Zhang, J., Liu, Y., Zhou, X., Waanders, A.J., Zwijnenburg, D.A., Raman, P., Brors, B., Weber, U.D., Northcott, P.A., Pajtler, K.W., Kool, M., Piro, R.M., Korbel, J.O., Schlesner, M., Eils, R., Jones, D.T.W., Lichter, P., Chavez, L., Zapatka, M., Pfister, S.M., 2018. The landscape of genomic alterations across childhood cancers. Nature 555, 321-327.

https://doi.org/10.1038/nature25480

Gry, M., Rimini, R., Strömberg, S., Asplund, A., Pontén, F., Uhlén, M., Nilsson, P., 2009. Correlations between RNA and protein expression profiles in 23 human cell lines. BMC Genomics 10, 365. https://doi.org/10.1186/1471-2164-10-365

Gustafsson, M., Gawel, D.R., Alfredsson, L., Baranzini, S., Björkander, J., Blomgran, R., Hellberg, S., Eklund, D., Ernerudh, J., Kockum, I., Konstantinell, A., Lahesmaa, R., Lentini, A., Liljenström, H.R.I., Mattson, L., Matussek, A., Mellergård, J., Mendez, M., Olsson, T., Pujana, M.A., Rasool, O., Serra-Musach, J., Stenmarker, M., Tripathi, S., Viitala, M., Wang, H., Zhang, H., Nestor, C.E., Benson, M., 2015. A validated gene regulatory network and GWAS identifies early regulators of T cellassociated diseases. Sci. Transl. Med. 7, 313ra178. https://doi.org/10.1126/scitranslmed.aad2722

Hafler, D.A., 2004. Multiple sclerosis. J. Clin. Invest. 113, 788-794. https://doi.org/10.1172/JCI21357

Heinz, S., Benner, C., Spann, N., Bertolino, E., Lin, Y.C., Laslo, P., Cheng, J.X., Murre, C., Singh, H., Glass, C.K., 2010. Simple 
combinations of lineage-determining transcription factors prime cis-regulatory elements required for macrophage and $\mathrm{B}$ cell identities. Mol. Cell 38, 576-589. https://doi.org/10.1016/j.molcel.2010.05.004

Husebye, E.S., Perheentupa, J., Rautemaa, R., Kämpe, O., 2009. Clinical manifestations and management of patients with autoimmune polyendocrine syndrome type I. J. Intern. Med. 265, 514-529. https://doi.org/10.1111/j.13652796.2009.02090.x

Jeong, H.-H., Yalamanchili, H.K., Guo, C., Shulman, J.M., Liu, Z., 2018. An ultra-fast and scalable quantification pipeline for transposable elements from next generation sequencing data. Pac. Symp. Biocomput. Pac. Symp. Biocomput. 23, 168-179.

Jin, B., Sun, T., Yu, X.-H., Yang, Y.-X., Yeo, A.E.T., 2012. The effects of TLR activation on T-cell development and differentiation. Clin. Dev. Immunol. 2012, 836485. https://doi.org/10.1155/2012/836485

Jones, P.A., Baylin, S.B., 2002. The fundamental role of epigenetic events in cancer. Nat. Rev. Genet. 3, 415-428. https://doi.org/10.1038/nrg816

Jones, P.A., Liang, G., 2009. Rethinking how DNA methylation patterns are maintained. Nat. Rev. Genet. 10, 805-811. https://doi.org/10.1038/nrg2651

Josefowicz, S.Z., Lu, L.-F., Rudensky, A.Y., 2012. Regulatory T cells: mechanisms of differentiation and function. Annu. Rev. Immunol. 30, 531-564.

https://doi.org/10.1146/annurev.immunol.25.022106.141623

Klein, L., Kyewski, B., Allen, P.M., Hogquist, K.A., 2014. Positive and negative selection of the T cell repertoire: what thymocytes see (and don't see). Nat. Rev. Immunol. 14, 377-391. https://doi.org/10.1038/nri3667

Kong, Y., Rose, C.M., Cass, A.A., Williams, A.G., Darwish, M., Lianoglou, S., Haverty, P.M., Tong, A.-J., Blanchette, C., Albert, M.L., Mellman, I., Bourgon, R., Greally, J., Jhunjhunwala, S., Chen-Harris, H., 2019. Transposable element expression in tumors is associated with immune infiltration and increased antigenicity. Nat. Commun. 10, 5228.

https://doi.org/10.1038/s41467-019-13035-2

Lanciano, S., Cristofari, G., 2020. Measuring and interpreting transposable element expression. Nat. Rev. Genet. 21, 721-736. https://doi.org/10.1038/s41576-020-0251-y

Li, C., Jiang, P., Wei, S., Xu, X., Wang, J., 2020. Regulatory T cells in tumor microenvironment: new mechanisms, potential 
therapeutic strategies and future prospects. Mol. Cancer 19, 116. https://doi.org/10.1186/s12943-020-01234-1

Li, Z., Schulz, M.H., Look, T., Begemann, M., Zenke, M., Costa, I.G., 2019. Identification of transcription factor binding sites using ATAC-seq. Genome Biol. 20, 45. https://doi.org/10.1186/s13059-019-1642-2

Lio, C.-W.J., Yuita, H., Rao, A., 2019. Dysregulation of the TET family of epigenetic regulators in lymphoid and myeloid malignancies. Blood 134, 1487-1497. https://doi.org/10.1182/blood.2019791475

Liu, M., Ohtani, H., Zhou, W., Ørskov, A.D., Charlet, J., Zhang, Y.W., Shen, H., Baylin, S.B., Liang, G., Grønbæk, K., Jones, P.A., 2016. Vitamin $C$ increases viral mimicry induced by 5-aza-2'deoxycytidine. Proc. Natl. Acad. Sci. U. S. A. 113, 10238-10244. https://doi.org/10.1073/pnas.1612262113

Liu, Y., Beyer, A., Aebersold, R., 2016. On the Dependency of Cellular Protein Levels on mRNA Abundance. Cell 165, 535-550. https://doi.org/10.1016/j.cell.2016.03.014

Luchtel, R.A., Bhagat, T., Pradhan, K., Jacobs, W.R., Levine, M., Verma, A., Shenoy, N., 2020. High-dose ascorbic acid synergizes with anti-PD1 in a lymphoma mouse model. Proc. Natl. Acad. Sci. U. S. A. 117, 1666-1677. https://doi.org/10.1073/pnas.1908158117 Luckheeram, R.V., Zhou, R., Verma, A.D., Xia, B., 2012. CD4+T cells: differentiation and functions. Clin. Dev. Immunol. 2012, 925135. https://doi.org/10.1155/2012/925135

Ma, X., Liu, Yu, Liu, Yanling, Alexandrov, L.B., Edmonson, M.N., Gawad, C., Zhou, X., Li, Y., Rusch, M.C., Easton, J., Huether, R., Gonzalez-Pena, V., Wilkinson, M.R., Hermida, L.C., Davis, S., Sioson, E., Pounds, S., Cao, X., Ries, R.E., Wang, Z., Chen, X., Dong, L., Diskin, S.J., Smith, M.A., Guidry Auvil, J.M., Meltzer, P.S., Lau, C.C., Perlman, E.J., Maris, J.M., Meshinchi, S., Hunger, S.P., Gerhard, D.S., Zhang, J., 2018. Pan-cancer genome and transcriptome analyses of 1,699 paediatric leukaemias and solid tumours. Nature 555, 371-376. https://doi.org/10.1038/nature25795

Magnusson, R., Mariotti, G.P., Köpsén, M., Lövfors, W., Gawel, D.R., Jörnsten, R., Linde, J., Nordling, T.E.M., Nyman, E., Schulze, S., Nestor, C.E., Zhang, H., Cedersund, G., Benson, M., Tjärnberg, A., Gustafsson, M., 2017. LASSIM-A network inference toolbox for genome-wide mechanistic modeling. PLoS Comput. Biol. 13, e1005608. https://doi.org/10.1371/journal.pcbi.1005608 
Maier, T., Güell, M., Serrano, L., 2009. Correlation of mRNA and protein in complex biological samples. FEBS Lett. 583, 39663973. https://doi.org/10.1016/j.febslet.2009.10.036

Malek, T.R., 2008. The biology of interleukin-2. Annu. Rev. Immunol. $26,453-479$.

https://doi.org/10.1146/annurev.immunol.26.021607.090357

Marçais, A., Waast, L., Bruneau, J., Hanssens, K., Asnafi, V., Gaulard, P., Suarez, F., Dubreuil, P., Gessain, A., Hermine, O., Pique, C., 2017. Adult $\mathrm{T}$ cell leukemia aggressivenness correlates with loss of both 5 -hydroxymethylcytosine and TET2 expression. Oncotarget 8, 52256-52268. https://doi.org/10.18632/oncotarget.13665

Martins, A.L., Walavalkar, N.M., Anderson, W.D., Zang, C., Guertin, M.J., 2018. Universal correction of enzymatic sequence bias reveals molecular signatures of protein/DNA interactions. Nucleic Acids Res. 46, e9. https://doi.org/10.1093/nar/gkx1053

Miyaura, H., Iwata, M., 2002. Direct and indirect inhibition of Th1 development by progesterone and glucocorticoids. J. Immunol. Baltim. Md 1950 168, 1087-1094. https://doi.org/10.4049/jimmunol.168.3.1087

Moertel, C.G., Fleming, T.R., Creagan, E.T., Rubin, J., O’Connell, M.J., Ames, M.M., 1985. High-dose vitamin C versus placebo in the treatment of patients with advanced cancer who have had no prior chemotherapy. A randomized double-blind comparison. N. Engl. J. Med. 312, 137-141. https://doi.org/10.1056/NEJM198501173120301

Mohammad, I., Starskaia, I., Nagy, T., Guo, J., Yatkin, E., Väänänen, K., Watford, W.T., Chen, Z., 2018. Estrogen receptor a contributes to $\mathrm{T}$ cell-mediated autoimmune inflammation by promoting $\mathrm{T}$ cell activation and proliferation. Sci. Signal. 11, eaap9415. https://doi.org/10.1126/scisignal.aap9415

Moroni, G., Ponticelli, C., 2016. Pregnancy in women with systemic lupus erythematosus (SLE). Eur. J. Intern. Med. 32, 7-12. https://doi.org/10.1016/j.ejim.2016.04.005

Ness, K.K., Armenian, S.H., Kadan-Lottick, N., Gurney, J.G., 2011. Adverse effects of treatment in childhood acute lymphoblastic leukemia: general overview and implications for long-term cardiac health. Expert Rev. Hematol. 4, 185-197. https://doi.org/10.1586/ehm.11.8

Ohtani, H., Ørskov, A.D., Helbo, A.S., Gillberg, L., Liu, M., Zhou, W., Ungerstedt, J., Hellström-Lindberg, E., Sun, W., Liang, G., Jones, P.A., Grønbæk, K., 2020. Activation of a Subset of Evolutionarily Young Transposable Elements and Innate 
Immunity Are Linked to Clinical Responses to 5-Azacytidine. Cancer Res. 80, 2441-2450. https://doi.org/10.1158/o0o85472.CAN-19-1696

Paces, J., Pavlícek, A., Paces, V., 2002. HERVd: database of human endogenous retroviruses. Nucleic Acids Res. 30, 205-206. https://doi.org/10.1093/nar/30.1.205

Padayatty, S.J., Sun, H., Wang, Y., Riordan, H.D., Hewitt, S.M., Katz, A., Wesley, R.A., Levine, M., 2004. Vitamin C pharmacokinetics: implications for oral and intravenous use. Ann. Intern. Med. 140, 533-537. https://doi.org/10.7326/0003-4819-140-7-200404060-00010

Patro, R., Duggal, G., Love, M.I., Irizarry, R.A., Kingsford, C., 2017. Salmon provides fast and bias-aware quantification of transcript expression. Nat. Methods 14, 417-419. https://doi.org/10.1038/nmeth.4197

Patro, R., Mount, S.M., Kingsford, C., 2014. Sailfish enables alignmentfree isoform quantification from RNA-seq reads using lightweight algorithms. Nat. Biotechnol. 32, 462-464. https://doi.org/10.1038/nbt.2862

Payne, S.H., 2015. The utility of protein and mRNA correlation. Trends Biochem. Sci. 40, 1-3. https://doi.org/10.1016/j.tibs.2014.10.010

Pertea, M., Pertea, G.M., Antonescu, C.M., Chang, T.-C., Mendell, J.T., Salzberg, S.L., 2015. StringTie enables improved reconstruction of a transcriptome from RNA-seq reads. Nat. Biotechnol. 33, 290-295. https://doi.org/10.1038/nbt.3122

Piccinni, M.P., Giudizi, M.G., Biagiotti, R., Beloni, L., Giannarini, L., Sampognaro, S., Parronchi, P., Manetti, R., Annunziato, F., Livi, C., 1995. Progesterone favors the development of human T helper cells producing Th2-type cytokines and promotes both IL-4 production and membrane CD30 expression in established Th1 cell clones. J. Immunol. Baltim. Md 1950 155, 128-133.

Piper, J., Elze, M.C., Cauchy, P., Cockerill, P.N., Bonifer, C., Ott, S., 2013. Wellington: a novel method for the accurate identification of digital genomic footprints from DNase-seq data. Nucleic Acids Res. 41, e201. https://doi.org/10.1093/nar/gkt850

Polman, C.H., O’Connor, P.W., Havrdova, E., Hutchinson, M., Kappos, L., Miller, D.H., Phillips, J.T., Lublin, F.D., Giovannoni, G., Wajgt, A., Toal, M., Lynn, F., Panzara, M.A., Sandrock, A.W., AFFIRM Investigators, 2006. A randomized, placebo-controlled trial of natalizumab for relapsing multiple sclerosis. N. Engl. J. Med. 354, 899-910. https://doi.org/10.1056/NEJMoa044397 
Prousek, J., 2007. Fenton chemistry in biology and medicine. Pure Appl. Chem. 79, 2325-2338. https://doi.org/10.1351/pac200779122325

Pui, C.-H., Relling, M.V., Downing, J.R., 2004. Acute lymphoblastic leukemia. N. Engl. J. Med. 350, 1535-1548. https://doi.org/10.1056/NEJMra023001

Rivers, J.M., 1987. Safety of high-level vitamin C ingestion. Ann. N. Y. Acad. Sci. 498, 445-454. https://doi.org/10.1111/j.17496632.1987.tb23780.x

Rodriguez, J.M., Maietta, P., Ezkurdia, I., Pietrelli, A., Wesselink, J.-J., Lopez, G., Valencia, A., Tress, M.L., 2013. APPRIS: annotation of principal and alternative splice isoforms. Nucleic Acids Res. 41, D110-117. https://doi.org/10.1093/nar/gks1058

Roulois, D., Loo Yau, H., Singhania, R., Wang, Y., Danesh, A., Shen, S.Y., Han, H., Liang, G., Jones, P.A., Pugh, T.J., O'Brien, C., De Carvalho, D.D., 2015. DNA-Demethylating Agents Target Colorectal Cancer Cells by Inducing Viral Mimicry by Endogenous Transcripts. Cell 162, 961-973. https://doi.org/10.1016/j.cell.2015.07.056

Saini, S.K., Ørskov, A.D., Bjerregaard, A.-M., Unnikrishnan, A., Holmberg-Thydén, S., Borch, A., Jensen, K.V., Anande, G., Bentzen, A.K., Marquard, A.M., Tamhane, T., Treppendahl, M.B., Gang, A.O., Dufva, I.H., Szallasi, Z., Ternette, N., Pedersen, A.G., Eklund, A.C., Pimanda, J., Grønbæk, K., Hadrup, S.R., 2020. Human endogenous retroviruses form a reservoir of $\mathrm{T}$ cell targets in hematological cancers. Nat. Commun. 11, 5660. https://doi.org/10.1038/s41467-02019464-8

Schmiegelow, K., Forestier, E., Hellebostad, M., Heyman, M., Kristinsson, J., Söderhäll, S., Taskinen, M., Nordic Society of Paediatric Haematology and Oncology, 2010. Long-term results of NOPHO ALL-92 and ALL-2000 studies of childhood acute lymphoblastic leukemia. Leukemia 24, 345-354. https://doi.org/10.1038/leu.2009.251

Schwartz, R.H., 2003. T cell anergy. Annu. Rev. Immunol. 21, 305-334. https://doi.org/10.1146/annurev.immunol.21.120601.141110

Scourzic, L., Mouly, E., Bernard, O.A., 2015. TET proteins and the control of cytosine demethylation in cancer. Genome Med. 7, 9. https://doi.org/10.1186/s13073-015-0134-6

Shah, N.M., Lai, P.F., Imami, N., Johnson, M.R., 2019. ProgesteroneRelated Immune Modulation of Pregnancy and Labor. Front. Endocrinol. 10, 198. https://doi.org/10.3389/fendo.2019.00198 
Shaulian, E., Karin, M., 2002. AP-1 as a regulator of cell life and death. Nat. Cell Biol. 4, E131-136. https://doi.org/10.1038/ncbo502e131

Simon, J.M., Giresi, P.G., Davis, I.J., Lieb, J.D., 2012. Using formaldehyde-assisted isolation of regulatory elements (FAIRE) to isolate active regulatory DNA. Nat. Protoc. 7, 256-267. https://doi.org/10.1038/nprot.2011.444

Smith-Garvin, J.E., Koretzky, G.A., Jordan, M.S., 2009. T cell activation. Annu. Rev. Immunol. 27, 591-619. https://doi.org/10.1146/annurev.immunol.021908.132706

Song, L., Crawford, G.E., 2010. DNase-seq: a high-resolution technique for mapping active gene regulatory elements across the genome from mammalian cells. Cold Spring Harb. Protoc. 2010, pdb.prot5384. https://doi.org/10.1101/pdb.prot5384

Sospedra, M., Martin, R., 2005. Immunology of multiple sclerosis. Annu. Rev. Immunol. 23, 683-747. https://doi.org/10.1146/annurev.immunol.23.021704.115707

Sproul, D., Kitchen, R.R., Nestor, C.E., Dixon, J.M., Sims, A.H., Harrison, D.J., Ramsahoye, B.H., Meehan, R.R., 2012. Tissue of origin determines cancer-associated $\mathrm{CpG}$ island promoter hypermethylation patterns. Genome Biol. 13, R84. https://doi.org/10.1186/gb-2012-13-10-r84

Stites, D.P., Siiteri, P.K., 1983. Steroids as immunosuppressants in pregnancy. Immunol. Rev. 75, 117-138. https://doi.org/10.1111/j.1600-065x.1983.tbo1093.x

Takahama, Y., 2006. Journey through the thymus: stromal guides for T-cell development and selection. Nat. Rev. Immunol. 6, 127135. https://doi.org/10.1038/nri1781

Tauscher, A.E., Fleischer, A.B., Phelps, K.C., Feldman, S.R., 2002. Psoriasis and pregnancy. J. Cutan. Med. Surg. 6, 561-570. https://doi.org/10.1007/s10227-001-0147-1

Teo, G., Vogel, C., Ghosh, D., Kim, S., Choi, H., 2014. PECA: a novel statistical tool for deconvoluting time-dependent gene expression regulation. J. Proteome Res. 13, 29-37. https://doi.org/10.1021/pr400855q

Theofilopoulos, A.N., Kono, D.H., Baccala, R., 2017. The multiple pathways to autoimmunity. Nat. Immunol. 18, 716-724. https://doi.org/10.1038/ni.3731

Ueda, S., Masutani, H., Nakamura, H., Tanaka, T., Ueno, M., Yodoi, J., 2002. Redox control of cell death. Antioxid. Redox Signal. 4, 405-414. https://doi.org/10.1089/15230860260196209

Van Vlierberghe, P., Ambesi-Impiombato, A., De Keersmaecker, K., Hadler, M., Paietta, E., Tallman, M.S., Rowe, J.M., Forne, C., 
Rue, M., Ferrando, A.A., 2013. Prognostic relevance of integrated genetic profiling in adult T-cell acute lymphoblastic leukemia. Blood 122, 74-82. https://doi.org/10.1182/blood2013-03-491092

Van Vlierberghe, P., Ambesi-Impiombato, A., Perez-Garcia, A., Haydu, J.E., Rigo, I., Hadler, M., Tosello, V., Della Gatta, G., Paietta, E., Racevskis, J., Wiernik, P.H., Luger, S.M., Rowe, J.M., Rue, M., Ferrando, A.A., 2011. ETV6 mutations in early immature human T cell leukemias. J. Exp. Med. 208, 2571-2579.

https://doi.org/10.1084/jem.20112239

Vierstra, J., Stamatoyannopoulos, J.A., 2016. Genomic footprinting. Nat. Methods 13, 213-221.

https://doi.org/10.1038/nmeth.3768

Vogel, C., Marcotte, E.M., 2012. Insights into the regulation of protein abundance from proteomic and transcriptomic analyses. Nat. Rev. Genet. 13, 227-232. https://doi.org/10.1038/nrg3185

Wang, J., Jelcic, I., Mühlenbruch, L., Haunerdinger, V., Toussaint, N.C., Zhao, Y., Cruciani, C., Faigle, W., Naghavian, R., Foege, M., Binder, T.M.C., Eiermann, T., Opitz, L., Fuentes-Font, L., Reynolds, R., Kwok, W.W., Nguyen, J.T., Lee, J.-H., Lutterotti, A., Münz, C., Rammensee, H.-G., Hauri-Hohl, M., Sospedra, M., Stevanovic, S., Martin, R., 2020. HLA-DR15 Molecules Jointly Shape an Autoreactive T Cell Repertoire in Multiple Sclerosis. Cell 183, 1264-1281.e20. https://doi.org/10.1016/j.cell.2020.09.054

Wehr, P., Purvis, H., Law, S.-C., Thomas, R., 2019. Dendritic cells, T cells and their interaction in rheumatoid arthritis. Clin. Exp. Immunol. 196, 12-27. https://doi.org/10.1111/cei.13256

Weng, A.P., Ferrando, A.A., Lee, W., Morris, J.P., Silverman, L.B., Sanchez-Irizarry, C., Blacklow, S.C., Look, A.T., Aster, J.C., 2004. Activating mutations of NOTCH1 in human T cell acute lymphoblastic leukemia. Science 306, 269-271. https://doi.org/10.1126/science.1102160

Wilhelm, M., Schlegl, J., Hahne, H., Gholami, A.M., Lieberenz, M., Savitski, M.M., Ziegler, E., Butzmann, L., Gessulat, S., Marx, H., Mathieson, T., Lemeer, S., Schnatbaum, K., Reimer, U., Wenschuh, H., Mollenhauer, M., Slotta-Huspenina, J., Boese, J.-H., Bantscheff, M., Gerstmair, A., Faerber, F., Kuster, B., 2014. Mass-spectrometry-based draft of the human proteome. Nature 509, 582-587. https://doi.org/10.1038/nature13319

Wu, X., Zhang, Y., 2017. TET-mediated active DNA demethylation: mechanism, function and beyond. Nat. Rev. Genet. 18, 517-534. https://doi.org/10.1038/nrg.2017.33 
Yan, F., Powell, D.R., Curtis, D.J., Wong, N.C., 2020. From reads to insight: a hitchhiker's guide to ATAC-seq data analysis. Genome Biol. 21, 22. https://doi.org/10.1186/s13059-020-1929-3

Yang, S., Fujikado, N., Kolodin, D., Benoist, C., Mathis, D., 2015. Immune tolerance. Regulatory $\mathrm{T}$ cells generated early in life play a distinct role in maintaining self-tolerance. Science 348, 589594. https://doi.org/10.1126/science.aaa7017

Yukawa, M., Jagannathan, S., Vallabh, S., Kartashov, A.V., Chen, X., Weirauch, M.T., Barski, A., 2020. AP-1 activity induced by costimulation is required for chromatin opening during $\mathrm{T}$ cell activation. J. Exp. Med. 217, e20182009. https://doi.org/10.1084/jem.20182009

Yun, J., Mullarky, E., Lu, C., Bosch, K.N., Kavalier, A., Rivera, K., Roper, J., Chio, I.I.C., Giannopoulou, E.G., Rago, C., Muley, A., Asara, J.M., Paik, J., Elemento, O., Chen, Z., Pappin, D.J., Dow, L.E., Papadopoulos, N., Gross, S.S., Cantley, L.C., 2015. Vitamin C selectively kills KRAS and BRAF mutant colorectal cancer cells by targeting GAPDH. Science 350, 1391-1396. https://doi.org/10.1126/science.aaa5004

Zhang, J., Ding, L., Holmfeldt, L., Wu, G., Heatley, S.L., Payne-Turner, D., Easton, J., Chen, X., Wang, J., Rusch, M., Lu, C., Chen, S.-C., Wei, L., Collins-Underwood, J.R., Ma, J., Roberts, K.G., Pounds, S.B., Ulyanov, A., Becksfort, J., Gupta, P., Huether, R., Kriwacki, R.W., Parker, M., McGoldrick, D.J., Zhao, D., Alford, D., Espy, S., Bobba, K.C., Song, G., Pei, D., Cheng, C., Roberts, S., Barbato, M.I., Campana, D., Coustan-Smith, E., Shurtleff, S.A., Raimondi, S.C., Kleppe, M., Cools, J., Shimano, K.A., Hermiston, M.L., Doulatov, S., Eppert, K., Laurenti, E., Notta, F., Dick, J.E., Basso, G., Hunger, S.P., Loh, M.L., Devidas, M., Wood, B., Winter, S., Dunsmore, K.P., Fulton, R.S., Fulton, L.L., Hong, X., Harris, C.C., Dooling, D.J., Ochoa, K., Johnson, K.J., Obenauer, J.C., Evans, W.E., Pui, C.-H., Naeve, C.W., Ley, T.J., Mardis, E.R., Wilson, R.K., Downing, J.R., Mullighan, C.G., 2012. The genetic basis of early T-cell precursor acute lymphoblastic leukaemia. Nature 481, 157-163. https://doi.org/10.1038/nature10725

Zhao, J., Qin, B., Nikolay, R., Spahn, C.M.T., Zhang, G., 2019. Translatomics: The Global View of Translation. Int. J. Mol. Sci. 20, E212. https://doi.org/10.3390/ijms20010212 



\section{Papers}

The papers associated with this thesis have been removed for copyright reasons. For more details about these see:

https://doi.org/10.3384/9789179291044 


\section{FACULTY OF SCIENCE AND ENGINEERING}

Linköping Studies in Science and Technology, Dissertation No. 2186, 2021 Department of Bioinformatics

Linköping University

SE-581 83 Linköping, Sweden

wWw.liu.se
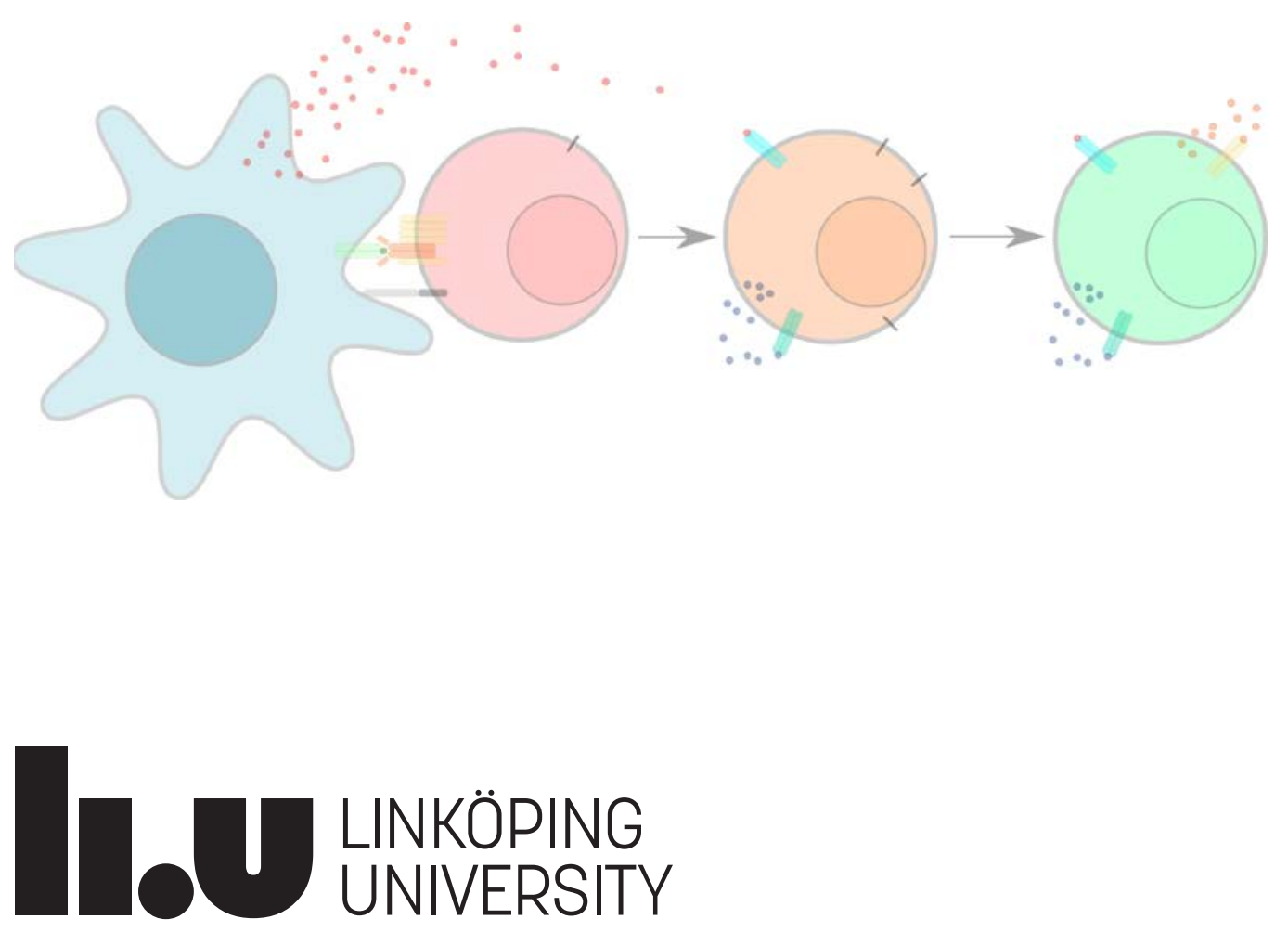